OPEN ACCESS

Edited by:

Doug LaRowe

University of Southern California,

United States

Reviewed by:

John Senko,

University of Akron, United States

Mustafa Yucel,

Middle East Technical University,

Turkey

*Correspondence:

Sebastian Haas

sebastian_haas@web.de;

s.haas@dal.ca

Specialty section:

This article was submitted to

Microbiological Chemistry

and Geomicrobiology,

a section of the journal

Frontiers in Microbiology

Received: 31 December 2017

Accepted: 13 April 2018

Published: 27 April 2018

Citation:

Haas $S$, de Beer D, Klatt JM,

Fink $A$, Rench RM, Hamilton $T L$, Meyer V, Kakuk B and Macalady JL

(2018) Low-Light Anoxygenic Photosynthesis and Fe-S-Biogeochemistry in a Microbial Mat

Front. Microbiol. 9:858. doi: 10.3389/fmicb.2018.00858

\section{Low-Light Anoxygenic Photosynthesis and Fe-S-Biogeochemistry in a Microbial Mat}

\author{
Sebastian Haas ${ }^{1,2 *}$, Dirk de Beer ${ }^{1}$, Judith M. Klatt ${ }^{1,3}$, Artur Fink ${ }^{1}$, \\ Rebecca McCauley Rench ${ }^{4}$, Trinity L. Hamilton ${ }^{5}$, Volker Meyer ${ }^{1}$, Brian Kakuk ${ }^{6}$ and \\ Jennifer L. Macalady ${ }^{4}$
}

\begin{abstract}
' Max Planck Institute for Marine Microbiology, Bremen, Germany, ${ }^{2}$ Department of Oceanography, Dalhousie University, Halifax, NS, Canada, ${ }^{3}$ Department of Earth and Environmental Sciences, University of Michigan, Ann Arbor, MI, United States, ${ }^{4}$ Geosciences Department, Pennsylvania State University, University Park, PA, United States, ${ }^{5}$ Department of Plant and Microbial Biology, University of Minnesota, Minneapolis, MN, United States, ${ }^{6}$ Bahamas Caves Research Foundation, Marsh Harbour, Bahamas
\end{abstract}

We report extremely low-light-adapted anoxygenic photosynthesis in a thick microbial mat in Magical Blue Hole, Abaco Island, The Bahamas. Sulfur cycling was reduced by iron oxides and organic carbon limitation. The mat grows below the halocline/oxycline at $30 \mathrm{~m}$ depth on the walls of the flooded sinkhole. In situ irradiance at the mat surface on a sunny December day was between 0.021 and $0.084 \mu \mathrm{mol}$ photons $\mathrm{m}^{-2} \mathrm{~s}^{-1}$, and UV light $(<400 \mathrm{~nm})$ was the most abundant part of the spectrum followed by green wavelengths $(475-530 \mathrm{~nm})$. We measured a light-dependent carbon uptake rate of $14.5 \mathrm{nmol} \mathrm{C} \mathrm{cm} \mathrm{cm}^{-2} \mathrm{~d}^{-1}$. A $16 \mathrm{~S}$ rRNA clone library of the green surface mat layer was dominated $(74 \%)$ by a cluster (>97\% sequence identity) of clones affiliated with Prosthecochloris, a genus within the green sulfur bacteria (GSB), which are obligate anoxygenic phototrophs. Typical photopigments of brown-colored GSB, bacteriochlorophyll $e$ and ( $\beta$-)isorenieratene, were abundant in mat samples and their absorption properties are well-adapted to harvest light in the available green and possibly even UV-A spectra. Sulfide from the water column $\left(3-6 \mu \mathrm{mol} \mathrm{L}^{-1}\right)$ was the main source of sulfide to the mat as sulfate reduction rates in the mats were very low (undetectable-99.2 $\mathrm{nmol} \mathrm{cm} \mathrm{cm}^{-3} \mathrm{~d}^{-1}$ ). The anoxic water column was oligotrophic and low in dissolved organic carbon (175-228 $\left.\mu \mathrm{mol} \mathrm{L}{ }^{-1}\right)$. High concentrations of pyrite $\left(\mathrm{FeS}_{2}\right.$; 1-47 $\mu \mathrm{mol} \mathrm{cm}{ }^{-3}$ ) together with low microbial process rates (sulfate reduction, $\mathrm{CO}_{2}$ fixation) indicate that the mats function as net sulfide sinks mainly by abiotic processes. We suggest that abundant Fe(III) $\left(4.3-22.2 \mu \mathrm{mol} \mathrm{cm}{ }^{-3}\right)$ is the major source of oxidizing power in the mat, and that abiotic Fe-S-reactions play the main role in pyrite formation. Limitation of sulfate reduction by low organic carbon availability along with the presence of abundant sulfide-scavenging iron oxides considerably slowed down sulfur cycling in these mats.

\footnotetext{
Keywords: anoxygenic photosynthesis, green sulfur bacteria, low-light photosynthesis, sulfide scavenging, microbial mat, bacteriochlorophyll e, iron-sulfur-cycling, Proterozoic ocean
}

Abbreviations: AVS, acid volatile sulfide; BChl, bacteriochlorophyll; CRS, chromium reducible sulfur; DIC, dissolved inorganic carbon; DOMS, diver operated microsensor system; GSB, green sulfur bacteria; MBH, magical blue hole; ORP, oxidation-reduction potential; PMT, photomultiplier; RT, retention time. 


\section{INTRODUCTION}

A significant part of the Earth's biosphere is exposed to regimes of extreme energy limitation, such as the terrestrial deep biosphere, the deep sea, and deep zones of most marine sediments. Energy limitation may have been even more significant on early Earth in the absence of oxygenic photosynthesis and the associated production of electron acceptors such as molecular oxygen and oxidized forms of nitrogen, iron, and sulfur. Although studies of low-energy communities are technically challenging and therefore relatively rare, they demonstrate how biotic and abiotic processes compete and interact, and may approximate conditions on early Earth and other planetary bodies.

The lower limits of biotic utilization of light are reached by anoxygenic photosynthesis, especially by members of the monophyletic clade of the GSB (Chlorobiaceae), which are obligate anaerobes and obligate anoxygenic phototrophs. They can proliferate at the interface of the sulfidic and photic zone in meromictic or eutrophic lakes (Montesinos et al., 1983; Mori et al., 2013; Crowe et al., 2014) or in microbial mats (Engel et al., 2004; Lau et al., 2009). The extremely low-lightadapted strain Prosthecochloris phaeobacteroides BS1 (formerly Chlorobium phaeobacteroides BS1; Manske et al., 2005; Imhoff and Thiel, 2010; Marschall et al., 2010) forms monospecific assemblages in the Black Sea chemocline and has been shown to fix inorganic carbon by the phototrophic oxidation of sulfide at light intensities as low as $0.015 \mu \mathrm{mol}$ photons $\mathrm{m}^{-2} \mathrm{~s}^{-1}$, which is five orders of magnitude lower than daylight (Manske et al., 2005). With estimated in situ carbon fixation rates as low as 200 to $1800 \mathrm{ng} \mathrm{C} \mathrm{m} \mathrm{m}^{-2} \mathrm{~d}^{-1}$, however, they have virtually no quantitative effect on the carbon and sulfur cycles in their habitat (Manske et al., 2005). Low-light-adapted GSB are referred to as brown-colored GSB, a non-monophyletic group of low-light specialists (Montesinos et al., 1983) that possess the BChl $a$ and $e$ as well as the carotenes isorenieratene and $\beta$-isorenieratene (Glaeser et al., 2002). BChl $e$ and these carotenes are responsible for light-harvesting and energy transfer to BChl $a$ in model GSB strains (Overmann et al., 1992; Hauska et al., 2001). GSB with this combination of pigments have an in vivo absorption maximum at $505 \mathrm{~nm}$ (Overmann et al., 1992). Since the physical light attenuation of water is lowest between 400 and $500 \mathrm{~nm}$ (Sogandares and Fry, 1997), they are able to thrive at great water depths.

Anoxygenic phototrophs can use a variety of electron donors, including nitrite (Griffin et al., 2007), ferrous iron (Widdel et al., 1993; in GSB: Heising et al., 1999), molecular hydrogen or reduced sulfur compounds (Pfennig, 1975; Overmann and Pfennig, 1989). Hydrogen sulfide is the electron donor most commonly used by GSB. It is converted according to the following stoichiometry:

$$
2 \mathrm{HS}^{-}+\mathrm{CO}_{2}+2 \mathrm{H}^{+} \rightarrow 2 \mathrm{~S}^{0}+\mathrm{CH}_{2} \mathrm{O}+\mathrm{H}_{2} \mathrm{O}
$$

Hydrogen sulfide is produced biologically by sulfate reduction, a process most prominent in marine sediments, but also frequently observed in biofilms and microbial mats (Canfield and Des Marais, 1991; Kühl and Jørgensen, 1992; Visscher et al.,
1992). Wieland et al. (2005) demonstrated how photosynthates in a microbial mat induced significantly increased sulfate reduction rates (SRRs) during the day. $\mathrm{CO}_{2}$ produced by sulfate reduction in turn enhanced photosynthesis. The same study also showed how large amounts of $\mathrm{Fe}(\mathrm{III})$ can affect sulfur cycling by precipitating sulfide. In the present study, we describe how a similar effect can slow down sulfur cycling in a mat that is significantly more limited in light and organic carbon.

Green sulfur bacteria may produce sulfate from hydrogen sulfide or more oxidized sulfur compounds (Overmann and Pfennig, 1989), but can also produce elemental sulfur $\left(\mathrm{S}^{0}\right)$, which is deposited extracellularly (Pfennig, 1975). The production of sulfur compounds of intermediate oxidation states rather than sulfate is common also to non-phototrophic sulfide oxidation processes. In fact, the presence of incompletely oxidized sulfur in the form of CRS can be used as an indication for sulfide oxidation (e.g., Thode-Andersen and Jørgensen, 1989; Holmkvist et al., 2011; Lichtschlag et al., 2013), because sulfate reduction typically does not produce sulfur compounds of intermediate oxidation states. In the absence of light, biological sulfide oxidation typically requires either oxygen, nitrate or nitrite as electron acceptor.

Blue holes are sinkholes: vertical, water-filled karst features open to the surface (Mylroie et al., 1995). Inland blue holes of the Bahamas are anchialine caves (Iliffe, 2000), landlocked bodies of water with subterranean connections to the ocean containing meromictic water columns with an upper freshwater lens separated from a lower saltwater column by a stable halocline (Seymour et al., 2007; Gonzalez et al., 2011). Each blue hole displays distinct geochemical traits, making them unique natural laboratories that allow exploring the limits of photosynthesis and the interplay between biotic and abiotic sulfur cycling. Inland blue holes are therefore of particular interest for geomicrobiology, because the unique geochemical features of each blue hole (e.g., depth of halocline, concentration of sulfide, water flow rates, organic matter input) are associated with the formation of specific types of microbial communities (Gonzalez et al., 2011). Few studies have been conducted on the microbiology of inland blue holes to date (Bottrell et al., 1991; Schwabe and Herbert, 2004; Macalady et al., 2010; Gonzalez et al., 2011).

A thick, orange-colored microbial mat with a thin green top layer was discovered in the suboxic, sulfidic water below the halo-chemocline of $\mathrm{MBH}$, The Bahamas (Gonzalez et al., 2011). The green color of surface cells and an abundance of GSB-affiliated 16S rRNA genes in clone libraries suggested the mats were phototrophic (Gonzalez et al., 2011). $\delta$-Proteobacteria were also highly abundant in the clone libraries, suggesting that sulfate reduction might be an important process in the mats (Gonzalez et al., 2011). We aimed to test the hypothesis that the mats are phototrophic and dominated by GSB that are optimally adapted to the quality and low intensity of the ambient light. Secondly, we aimed to test whether the sulfide needed for the GSB activity is supplied by sulfate reduction in the mats. We used a highly sensitive light detection system to quantify ambient irradiance and determine the light quality. The ambient spectra were compared with the absorption spectra of photopigments from the mats. Activities were determined by light dependency 
of carbon uptake and sulfate reduction rate measurements. To constrain the Fe-S-cycling in the mats, solid phase fractions of the iron and sulfur pools were quantified.

\section{MATERIALS AND METHODS}

\section{Study Site and Mat}

Magical Blue Hole (also known as Cherokee Road Extension Blue Hole, $26^{\circ} 22^{\prime} 31.96^{\prime \prime} \mathrm{N}, 77^{\circ} 6^{\prime} 14.91^{\prime \prime} \mathrm{W}$ ) is an anchialine sinkhole on Abaco Island (The Bahamas). It is approximately $80 \mathrm{~m}$ deep and has a surface diameter of approximately $10 \mathrm{~m}$. A stable halo- and chemocline is present at $25 \mathrm{~m}$ depth, separating oxic freshwater from anoxic, sulfidic seawater (Gonzalez et al., 2011). Below the surface, the diameter widens and the cave is roughly $40 \mathrm{~m}$ wide at $30 \mathrm{~m}$ depth. The narrow entry and the shading effect of the overhanging cave walls result in low light intensities below the halo-chemocline. The cave walls below the halo-chemocline are extensively covered by a thick microbial mat. It grows thickest (up to $\sim 6 \mathrm{~cm}$ ) on a ledge in the otherwise vertical cave wall situated at approximately $30 \mathrm{~m}$ depth. The mat is stratified with a thin green layer of fluffy biological material on top $(\sim 1 \mathrm{~mm})$, a gelatinous orange middle layer (up to $\sim 3 \mathrm{~cm}$ ) and a brown bottom-layer (up to $\sim 3 \mathrm{~cm}$; Figure 1).

\section{Sampling Techniques}

Geochemical parameters of the water column were measured in vertical profiles. Water samples were collected in lockable plastic syringes by a diver and sterile-filtered $(0.2 \mu \mathrm{m})$ immediately after sampling. Samples for dissolved inorganic and organic carbon analysis were stored at $4^{\circ} \mathrm{C}$ while samples for ammonium $\left(\mathrm{NH}_{4}{ }^{+}\right)$and nitrate $\left(\mathrm{NO}_{3}{ }^{-}\right)$quantification $(n=5$ for $30 \mathrm{~m}$ and $40 \mathrm{~m} ; n=2$ for remaining depths) were stored frozen. Total sulfide $\left(\mathrm{H}_{2} \mathrm{~S}+\mathrm{HS}^{-}+\mathrm{S}^{2-}\right)$ and sulfate $\left(\mathrm{SO}_{4}{ }^{2-} ; n=3\right.$ for all depths, respectively) samples were preserved by mixing 1:1 (v/v) with $20 \%$ Zn-acetate solution.

Samples for incubation with ${ }^{13} \mathrm{C}$-labeled substrates and subsamples for photosynthetic pigment analysis $(n=3)$ were taken by vacuuming the upper green part of the mat into lockable syringes. For clone library construction, a large piece of mat was cut out with a knife and immediately placed into a light-shielded and airtight plastic box by a diver for transport to the laboratory. Clone library samples were separated into the three natural layers based on location and color, preserved with RNAlater and stored at $4^{\circ} \mathrm{C}$ until analysis.

Microbial mat samples from around $30 \mathrm{~m}$ water depth were taken with push-cores, which were immediately closed by a diver with airtight plugs. Push-cores used to sample for pigment analysis ( $n=3$; core lengths: $1.2-5.7 \mathrm{~cm}$ ) and ${ }^{35} \mathrm{~S}$ incubation experiments ( $n=10$; lengths: $3.6-5.4 \mathrm{~cm}$ ) were wrapped in black tape to shield the samples from light. Cores for solid phase analyses were immediately cut into $0.6 \mathrm{~cm}$ slices (AVS/ CRS/ sulfate; lengths: $3.6-5.4 \mathrm{~cm}$ ) and $0.25 \mathrm{~cm}$ slices (dithionite reactive iron/ $\mathrm{S}^{0}$; lengths: $3.5-4.5 \mathrm{~cm}$ ) and fixed in $4 \mathrm{~mL} 5 \% \mathrm{Zn}$-acetate and $3 \mathrm{~mL} \mathrm{20 \%} \mathrm{Zn-acetate,} \mathrm{respectively.} \mathrm{Along} \mathrm{with} \mathrm{samples} \mathrm{for}$ pigment analysis, they were stored frozen. Samples for porosity $(n=4)$ and density $(n=1)$ measurements were also taken with push-cores.

\section{Solid Phase Analyses}

Mat porosity was determined as weight reduction after drying at $60^{\circ} \mathrm{C}$ in four mat cores (result: $0.92 \pm 0.02$ ). Density was determined as wet weight per mat volume. The density average of $0.6 \mathrm{~cm} / 1 \mathrm{~mL}$ slices $(n=8)$ from one core sample $(1.11 \pm 0.12 \mathrm{~g}$ $\mathrm{cm}^{-3}$ ) was used for conversions of mat weight into volume.

Acid volatile sulfide (AVS $=\mathrm{FeS}+\mathrm{Fe}_{3} \mathrm{~S}_{4}+\mathrm{H}_{2} \mathrm{~S}$ : Cornwell and Morse, 1987) and CRS (CRS $=S^{0}+\mathrm{FeS}_{2}$ : Cornwell and Morse, 1987) were extracted from six mat core samples in a two-step $\mathrm{HCl}$ and $\mathrm{Cr}(\mathrm{II})$ distillation according to Fossing and Jørgensen (1989). After distillation of the pellets, AVS and CRS trapped as $\mathrm{ZnS}$ were determined according to Cline (1969). Porewater sulfate content was quantified in the supernatant after a centrifugation step, which preceded these distillations. The detection limit was at $12.9 \mathrm{nmol} \mathrm{S} \mathrm{cm}^{-3}$. From five parallel cores, $S^{0}$ was extracted by methanol and measured as cyclo- $S_{8}$ by UPLC (Waters, United States) as described previously (Zopfi et al., 2004). Pyrite-S was defined as the difference between CRS and $\mathrm{S}^{0}$.

A citrate-acetate-dithionite solution was used to extract iron from three mat samples. The procedure extracts most crystalline and amorphous Fe(III) as well as FeS (Kostka and Luther, 1994). Extraction was preceded by a centrifugation step after which the supernatant was discarded. Since $\mathrm{Zn}$-acetate was used to preserve the samples, iron concentrations may be underestimated due to possible formation of non-extractable Fe-acetate. Dithionite extracts were analyzed with the ferrozine method according to Viollier et al. (2000).

\section{Geochemical Water Analyses}

Standard procedures were used to analyze chemical compounds in samples from the water column and in microbial mat extracts. Total sulfide was measured according to Cline (1969). Sulfate ion concentration was analyzed with ion chromatography (761 Compact Ion Chromatographer including 812 valve unit and 838 Advanced Sample Processor, Metrohm, Germany). Phosphate, nitrate and ammonium were quantified with a continuous flow analyzer $\left(\operatorname{San}^{++}\right.$, Skalar, Netherlands) using standard detection methods (Hansen and Koroleff, 2009). DIC was calculated as the difference between total carbon and non-purgeable organic carbon measured using a Total Carbon Analyzer (TOC-5000A, Shimadzu, Japan) after acidification and $\mathrm{N}_{2}$-purging.

\section{Photosynthetic Pigment Analysis}

Frozen mat cores were horizontally sliced with a resolution of $3 \mathrm{~mm}$. Pigments from both core slices and vacuumed surface layer samples were extracted with acetone as described previously (Al-Najjar et al., 2012). The filtered extract containing the pigments was then injected into a reversed-phase Highperformance liquid chromatograph (HPLC; 2695 Separations Module, Waters, United States). The pigments were separated according to Wright (1991) and absorption spectra were measured using a 996 Photodiode Array Detector. Identification 


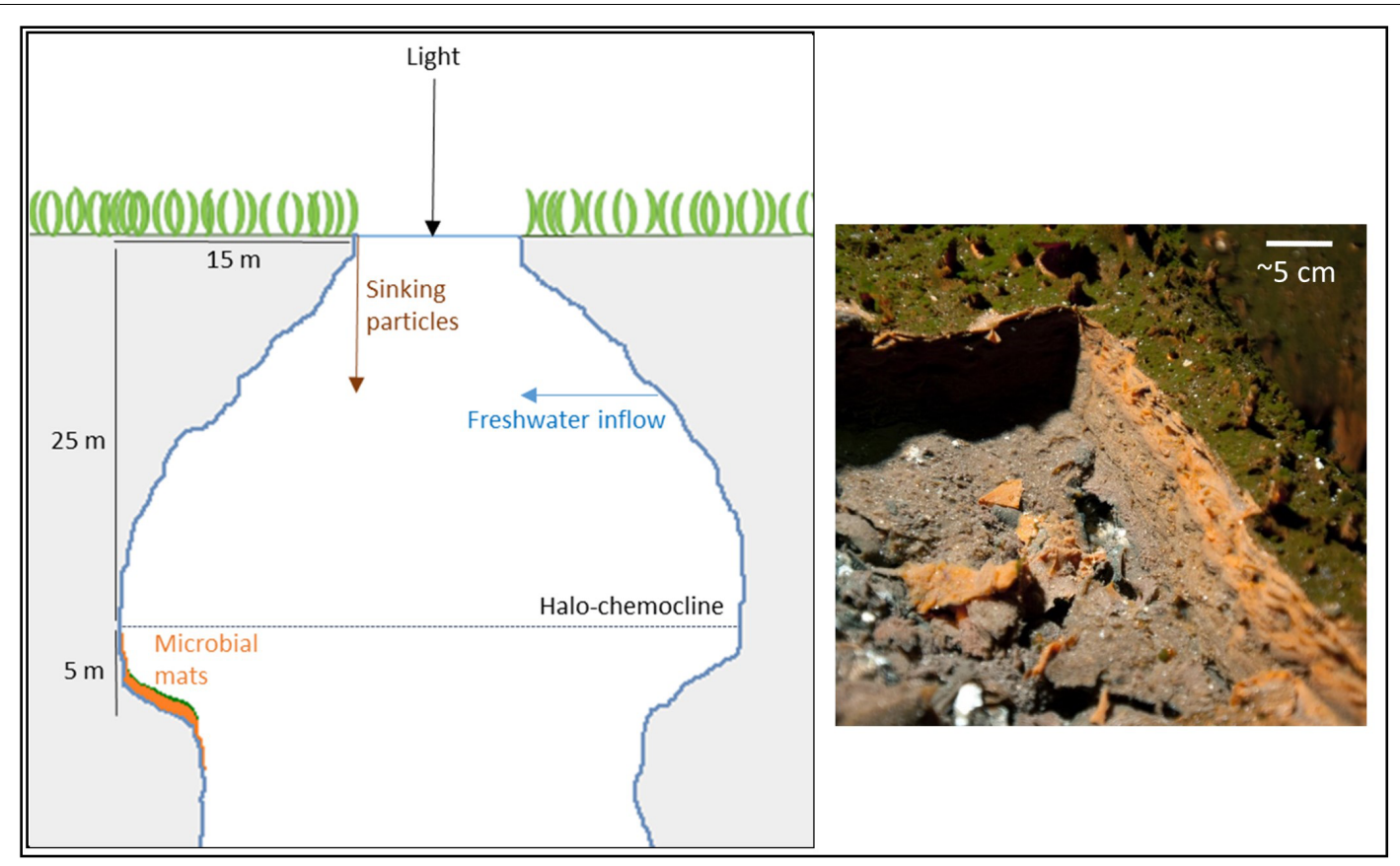

FIGURE 1 | Schematic drawing of Magical Blue Hole and a picture of the microbial mat of which a piece was cut out to reveal its three-layered structure.

of pigments was based on RT and absorption spectra. A $\beta$ carotene standard (beta-122; $0.813 \mathrm{mg} \mathrm{L}^{-1}$ in $100 \%$ acetone, Sigma-Aldrich, United States) and freeze-dried pure culture material of a low-light-adapted Prosthecochloris phaeobacteroides BS1strain isolated from the Black Sea chemocline by Overmann et al. (1992) (DSMZ Braunschweig) were analyzed in parallel as standards.

\section{Isotope Incubations for Process Rate Determination}

Rates of sulfate reduction, photoautotrophic carbon uptake and photoheterotrophic carbon uptake were assessed by incubations with isotopic labels. To assess SRRs inside the mat, the wholecore injection method based on radioactively labeled sulfate was carried out (Jørgensen, 1978). Under $\mathrm{N}_{2}$-atmosphere, $4 \mu \mathrm{l}$ per $\mathrm{cm}^{3}$ sample of radioactively labeled ${ }^{35} \mathrm{SO}_{4}{ }^{2-}$ in $\mathrm{Na}_{2} \mathrm{SO}_{4}$ carrier solution $\left(\sim 33 \mathrm{kBq} \mathrm{cm}{ }^{-3}\right)$ were vertically injected into push-cores (20 mm diameter) containing up to $20 \mathrm{~mL}$ freshly sampled microbial mat. Incubation under anoxic conditions and approximate in situ temperature was stopped after four $(n=6)$ and six $(n=4)$ hours by horizontally slicing the cores into $6 \mathrm{~mm}$ pieces and immediately mixing them $1: 1$ (v/v) with $20 \% \mathrm{Zn}$ acetate to stop sulfate reduction and fix hydrogen sulfide as $\mathrm{ZnS}$. After cold Cr(II) distillation (Kallmeyer et al., 2004; as modified by Røy et al., 2014), SRRs were determined (Jørgensen, 1978). A detection limit of 43.73 radioactive decays per minute (95\% confidence interval) was calculated based on means and standard deviations of sample blanks prepared (Kallmeyer et al., 2004).

To determine phototrophic carbon uptake, parts of the green surface layer of the mat were incubated in situ in cave water amended with labeled ${ }^{13} \mathrm{C}$-DIC $\left(\mathrm{NaH}^{13} \mathrm{CO}_{3}\right)$ or ${ }^{13} \mathrm{C}$-acetate $\left({ }^{13} \mathrm{CH}_{3}{ }^{12} \mathrm{CO}_{2} \mathrm{Na}\right)$ at $30 \mathrm{~m}$ depth in the center of the cave (maximum irradiance: $0.27 \mu \mathrm{mol}$ photons $\mathrm{m}^{-2} \mathrm{~s}^{-1}$; Figure 2A) for different time periods. Under anoxic $\mathrm{N}_{2}$-atmosphere and protected from high light exposure, samples were suspended in cave water (collected oxygen-free next to the mat) to a final volume of $500 \mathrm{ml}$. To ensure that the medium was completely anoxic, $18 \mu \mathrm{l}$ of $1 \mathrm{M} \mathrm{Na} \mathrm{N}_{2} \mathrm{~S}$ were added to a final sulfide concentration of $84 \mu \mathrm{mol} \mathrm{L}^{-1}$ at $\mathrm{pH} 6.85 \pm 0.35$. Glass vials $(6 \mathrm{~mL})$ with plastic lids featuring integrated septa were filled with medium containing the inoculum and isotope label depending on the treatment. Vials were supplemented with $73.8 \mathrm{nmol}$ of ${ }^{13} \mathrm{C}$-labeled DIC or ${ }^{13} \mathrm{C}$-labeled acetate, which resulted in ${ }^{13} \mathrm{C}$-labeling percentages of $10.5 \%$ for DIC and $50 \%$ for acetate, calculated based on observed in situ DIC concentrations and by assuming negligible in situ amounts of acetate. Triplicate aliquots for determination of natural isotope abundance were preserved before label addition. The ${ }^{13} \mathrm{C}$ content of three incubation vials was immediately preserved after addition of label $(t=0)$. The remainder of the closed incubation vials were incubated in the center of the blue hole at $30 \mathrm{~m}$ depth. Dark controls were incubated in light-shielded vials. One set of vials (low-light incubated: $n=3$; dark controls: $n=3$ ) was recovered after approximately 2 days and a second set after 6 days. At the prevailing daylight length of $10.5 \mathrm{~h}$, this corresponded to an incubation time in natural light of $24 \mathrm{~h}$ and $60 \mathrm{~h}$, respectively. All incubations were terminated by filtration through pre-combusted $\left(3 \mathrm{~h}, 450^{\circ} \mathrm{C}\right) \mathrm{GF} / \mathrm{F}$-filters $(0.7 \mu \mathrm{m}$ pore size), which were then dried at $60^{\circ} \mathrm{C}$ and subsequently treated and analyzed as described in Halm et al. (2012). Rates of total DIC and acetate assimilation were calculated as the increase in ${ }^{13} \mathrm{C} /{ }^{12} \mathrm{C}$ over time, corrected for natural abundance and ${ }^{13} \mathrm{C}$-labeling percentage. 
Carbon uptake rates per single cell and per mat area were calculated assuming that all cells were phototrophic and covering the mat surface without gaps. Phototrophic cell numbers per incubation vial were estimated based on total carbon determined by isotope ratio mass spectrometry per incubation vial and using literature values of cell radius $(0.6125 \mu \mathrm{m}$ in Black Sea strain $P$. phaeobacteroides BS1 cells cultivated at $0.1 \mu \mathrm{mol}$ photons $\mathrm{m}^{-2} \mathrm{~s}^{-1}$; Manske et al., 2005) and carbon content (106 fg $\mu \mathrm{m}^{-3}$; Nagata, 1986). They were corrected for carbon content determined in in situ cave water in the same way. To calculate quantum yields of photosynthesis - the amount of carbon fixed per incoming photons - we assumed a total absorptive cell surface of $0.716 \mathrm{~cm}^{2}$ per incubation vial. This was based on the product of the mean phototrophic cell numbers per vial $\left(1.16 \times 10^{8}\right.$ cells vial $^{-1}$ ) and an assumed single-cell absorption cross section (= average light absorbing cell surface) of $0.62 \mu \mathrm{m}^{2}$ (Black Sea P. phaeobacteroides: Marschall et al., 2010).

\section{Phylogenetic Analyses}

Mat microbial DNA was extracted from mat samples using chloroform-phenol extraction and 16S rRNA genes were amplified by PCR using Bacteria-specific $27 \mathrm{f}$ and $1492 \mathrm{r}$ primers as described in Macalady et al. (2008). One library was constructed for each mat layer. Potential chimeras were excluded from further analysis. Full length and partial sequences for the green layer $(n=74)$, orange layer $(n=65)$ and brown layer $(n=67)$ were obtained from the respective libraries. Sequences were aligned with the Silva aligner available at http://www.arb-silva. de, imported into ARB (Ludwig et al., 2004) and manually refined. Operational taxonomic units (OTUs) were identified using a sequence identity threshold of 97\% (0.03) using mothur (v.1.39.5) (Schloss et al., 2009). Taxonomy was assigned using BlastN (Altschul et al., 1997) and ARB (Ludwig et al., 2004). For phylogenetic analyses of sequences affiliated with Chlorobi and $\delta$-Proteobacteria, the top BLAST matches and nearest relative to each OTU in the ARB database were included. Representative sequences were added to an existing 16S rRNA alignment in $\mathrm{ARB}$, and manually refined. Maximum likelihood analyses were performed using RAxML (Stamatakis et al., 2008) with 1000 bootstrap replicates and the general time-reversible model with $\mathrm{G}+\mathrm{I}$ rate variation as determined by JModelTest v.2.1.10 (Darriba et al., 2012). The resulting trees were viewed and edited using iTOL $^{1}$ (Letunic and Bork, 2016). The 16S rRNA gene sequences recovered in this study were submitted to the GenBank database and assigned the following accession numbers: MG601241-MG601445.

\section{In Situ Measurements of Physico-Chemical Parameters}

For measurements of physico-chemical parameters, a datalogging device was designed and constructed to measure (i) downwelling scalar irradiance and (ii) physico-chemical parameters as well as (iii) spectra of downwelling light available to the mat. Irradiance was measured with a modified DOMS (Weber et al., 2007). A scalar irradiance sensor $\left(21.21 \mathrm{~mm}^{2}\right.$

${ }^{1}$ http://itol.embl.de/ sensing surface; US-SQS/LI, Walz, Germany) with a glass fiber was attached to a H5702-50 PMT (Hamamatsu Photonics, Japan). The control voltage and thereby the PMT sensitivity was scaled to ambient light conditions by a diver during measurements using a magnetic switch. The scalar irradiance sensor installed on the PMT measured irradiance over an angle of approximately $270^{\circ}$.

The DOMS logger, its $\mathrm{NiMH}$ rechargeable battery, the modified PMT, a cosine-corrected PAR sensor (QCP-2000; Biospherical Instruments, United States) and a multiparameter sonde (YSI 5200A, YSI, United States) equipped with sensors for pressure, ORP, pH, dissolved oxygen, temperature and salinity, were mounted on a vertical frame. This array could then be lowered into the blue hole with a rope for vertical profiling (descent rate: $4.3 \mathrm{~m} \mathrm{~min}^{-1}$ ) or made neutrally buoyant and moored to the cave wall. By attaching both PAR- and PMTsensors in one plane and upward orientation, parallel signals of the two sensors were obtained during the descent of the array through upper cave regions, where sufficient irradiance covered the sensitivity ranges of both light sensors. Using the PAR sensor's internal calibration, these overlapping data could be used to create a calibration curve for PMT measurements at greater depths.

The spectral quality of the light reaching the mat was determined by using a filter wheel containing optical longpass filters (FSR-GG-400 nm and $-475 \mathrm{~nm}$, FSR-OG-530 nm and $590 \mathrm{~nm}$, FSR-RG-645 nm; Newport, United States) in front of the sensor. The sensor was shaded from below with a movable cup and the filter wheel was operated manually by a diver. Based on the amplitude of irradiance reduction measured by the sensor after each filter switch, an in situ wavelength spectrum was obtained. The filters reduced the light intensity above their respective threshold by $10 \%$ (manufacturer information), for which the spectrum was corrected. The PMT covered an irradiance spectrum of 200-700 $\mathrm{nm}$ with sensitivity dropping above and below this spectrum. Within this spectrum, sensitivity was approximately even, except for slightly increased sensitivity in the wavelength range 500-680 $\mathrm{nm}$ (manufacturer information) that may have led to a small overestimation $(<2 \%)$ of the percentage of light from this wavelength range.

\section{RESULTS}

\section{Water Column Geochemistry and Irradiance}

Between 20 and $25 \mathrm{~m}$ depth, a distinct halo-chemocline was observed, below which the water was sulfidic and anoxic (Figure 2). Dissolved oxygen and temperature profiles displayed negative anomalies at about $10 \mathrm{~m}$ depth, probably due to lateral water inflow. Below the halo-chemocline, most chemical parameters and temperature remained approximately constant. Deviating from this trend, sulfide displayed two maxima, namely at $27.5 \mathrm{~m}$, i.e., directly below the halo-chemocline and close to the depth of highest mat abundance, and at $45 \mathrm{~m}$. There was no detectable sulfide above the halo-chemocline. Close to the depth of thickest mat growth, we observed a minimum in sulfide concentration (Figure 2D). 


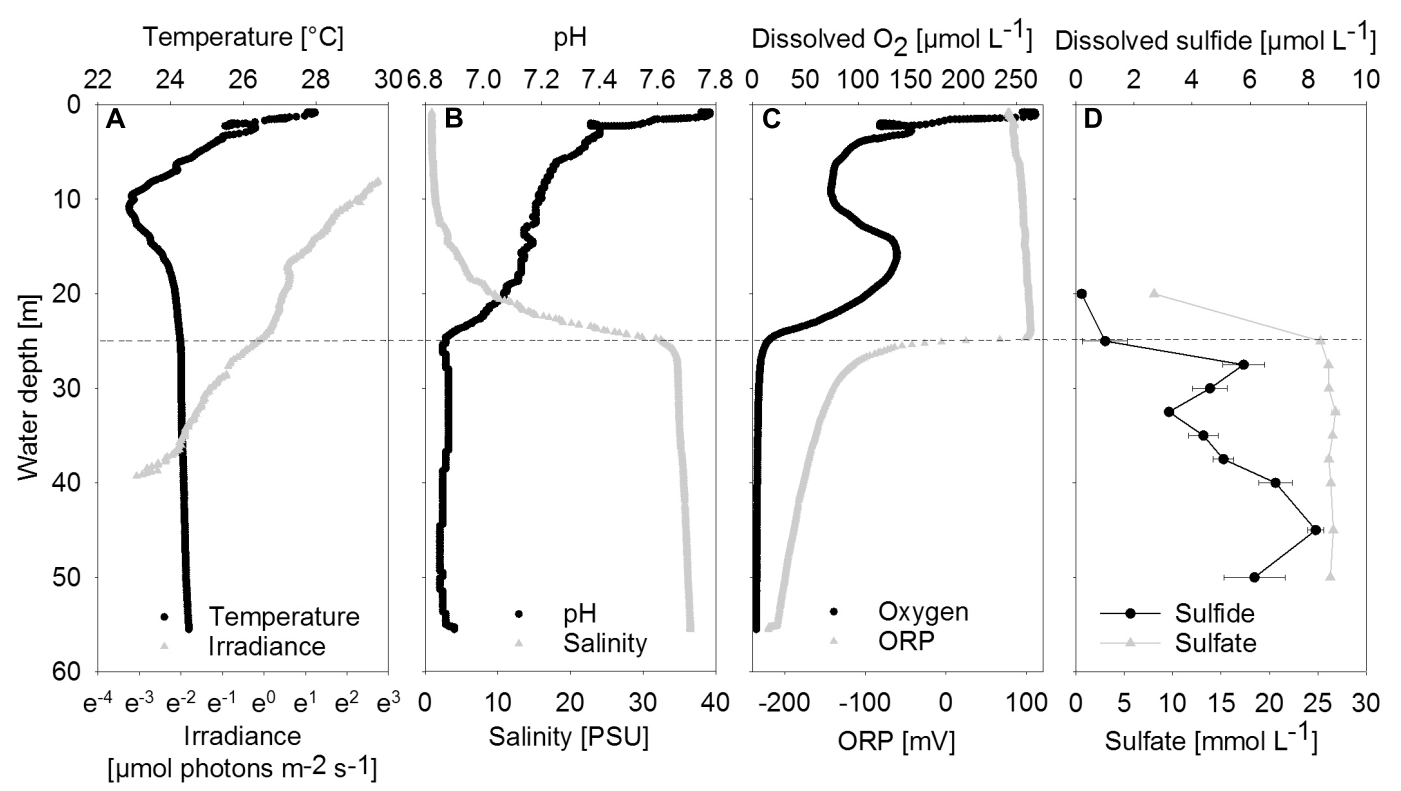

FIGURE 2 | Vertical profiles of chemical and physical parameters in the center of the water column. (A) Temperature and irradiance. Irradiance is plotted on a logarithmic scale. (B) PH and Salinity. (C) Dissolved oxygen and ORP, oxidation-reduction potential. (D) Dissolved sulfide and sulfate shown as mean concentrations $(n=3)$; error bars represent the standard deviation. The halo-chemocline is indicated by the dashed line at $25 \mathrm{~m}$.
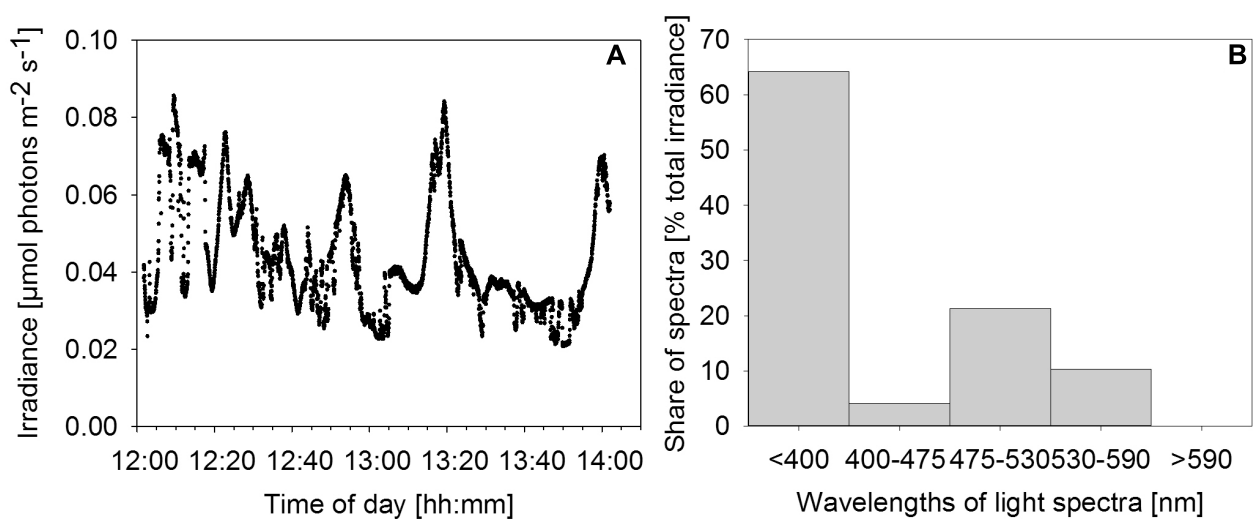

FIGURE 3 | Irradiance and relative wavelength abundance in situ. (A) Time series of in situ irradiance (270 $)$ available to the mat over $2 \mathrm{~h}$ starting at noon on December 1st, 2013. Weather: sunny with occasional clouds. (B) Percentage share of wavelength ranges in total downwelling light reaching the mat as determined by application of a series of longpass filters.

Nutrient and dissolved organic carbon concentrations were low (data not shown). Phosphate concentrations ranged between $0.2 \mu \mathrm{mol} \mathrm{L}^{-1}$ in the deep water $(40 \mathrm{~m})$ and $0.5 \mu \mathrm{mol} \mathrm{L}^{-1}$ in the halo-chemocline $(25 \mathrm{~m})$. Dissolved inorganic nitrogen was present below the halo-chemocline in the form of ammonium (approximately $10 \mu \mathrm{mol} \mathrm{L}^{-1}$ ) and above the halo-chemocline as nitrate $\left(3 \mu \mathrm{mol} \mathrm{L}^{-1}\right)$. Dissolved non-purgeable organic carbon concentrations ranged from $171 \mu \mathrm{mol} \mathrm{L}^{-1}$ in the deep water $(47 \mathrm{~m})$ to $258 \mu \mathrm{mol} \mathrm{L}^{-1}$ in the oxic water column $(9 \mathrm{~m})$ with intermediate concentrations around $30 \mathrm{~m}$.

Downwelling scalar irradiance declined with depth above $17 \mathrm{~m}$ and slightly more steeply with depth between 17 and $25 \mathrm{~m}$
(Figure 2A). Below the halo-chemocline, the light attenuation just below $25 \mathrm{~m}$ depth was stronger compared to the zone around $30 \mathrm{~m}$ depth. Irradiance at $30 \mathrm{~m}$ depth in the cave center was $0.27 \mu$ mol photons $\mathrm{m}^{-2} \mathrm{~s}^{-1}$. At the same depth near the cave wall - the site of thickest mat growth - irradiance was notably lower (Figure 3A), in the range of 0.021 to $0.084 \mu \mathrm{mol}$ photons $\mathrm{m}^{-2}$ $\mathrm{s}^{-1}$ during $2 \mathrm{~h}$ of measurement on a sunny day around noon. Occasional clouds caused sudden decreases in irradiance.

Measurements with a series of longpass filters revealed that the light attenuation varied substantially with wavelength. Intriguingly, $64 \%$ of the total irradiance available to the mat was light in the UV region of the spectrum $(<400 \mathrm{~nm})$. A second peak 
of relative wavelength abundance (21\%) was in the green part of the spectrum $(475-530 \mathrm{~nm})$. Red/near-IR light $(>590 \mathrm{~nm})$ did not reach the mat surface (Figure 3B).

\section{Clone Libraries Dominated by Green Sulfur Bacteria and $\delta$-Proteobacteria}

We created separate $16 \mathrm{~S}$ rRNA clone libraries from the green, the orange and the brown mat layers (Figure 4). The vast majority of the clones $(74 \%)$ from the thin green upper layer were affiliated with GSB (Chlorobi). GSB were much less abundant in the middle, orange layer, which was dominated by $\delta$-Proteobacteria related clones $(37 \%)$. In the brown bottom layer, clones affiliated with Aminicenantes (OP8), $\delta$-Proteobacteria, Planctomycetes and Chloroflexi were found most abundant, while GSB (1\%) were virtually absent.

The GSB-affiliated 16S rRNA gene sequences shared $>97 \%$ sequence identity and clustered together in the phylogenetic tree (Supplementary Figure S1). The MBH GSB cluster was situated in a wider cluster of Prosthecochloris reference sequences and the closest relative we identified was a clone from the chemocline of Sawmill Sink, a blue hole on the same island as MBH (Macalady et al., unpublished data). Unlike GSB, most $\delta$-Proteobacteria clones did not cluster with each other, but were each affiliated with a variety of uncultured reference sequences from diverse habitats (Supplementary Figure S2). A majority of clones were widely clustered with Desulfobacteraceae, and a few more with Syntrophobacteraceae.

\section{The Mat Contains the Photopigments Bacteriochlorophyll e and $(\beta$-)isorenieratene}

High-performance liquid chromatography analysis was used to assess whether the mat contains photopigments with absorption properties congruent with the in situ light quality. To a depth of $57 \mathrm{~mm}$ below the mat surface, a carotene identified as either isorenieratene or $\beta$-isorenieratene was abundant. It was detected in both $P$. phaeobacteroides BS1 pure culture reference material and in the mat based on identical absorption spectra and RTs (Figures 5B,D). Based on difference in RT, it was clearly distinguished from $\beta$-carotene, which has the same absorption spectrum as $\beta$-isorenieratene and isorenieratene (Takaichi, 2000; Fuciman et al., 2010). Further distinction could not be made, because the reference culture contained both $\beta$-isorenieratene and isorenieratene.

Additionally, we found $\mathrm{BChl} e$ to be abundant in the upper 0.8 to $15 \mathrm{~mm}$ of the three core samples as well as in most samples from vacuum-collected green mat surface material. It was identified based on identical absorption spectra and RT of a pigment from $P$. phaeobacteroides BS1 biomass. The absorption spectrum matched published ex vivo spectra of BChl $e$ (Gloe et al., 1975; Borrego et al., 1999), displaying a maximum at $468 \mathrm{~nm}$, a smaller peak at $651 \mathrm{~nm}$ and a double peak at $315 / 343$ nm (Figures 5A,C). In both $P$. phaeobacteroides BS1 and mat samples, we detected a variety of BChl $e$ homologs (Borrego and Garcia-Gil, 1994) that all displayed the described absorption

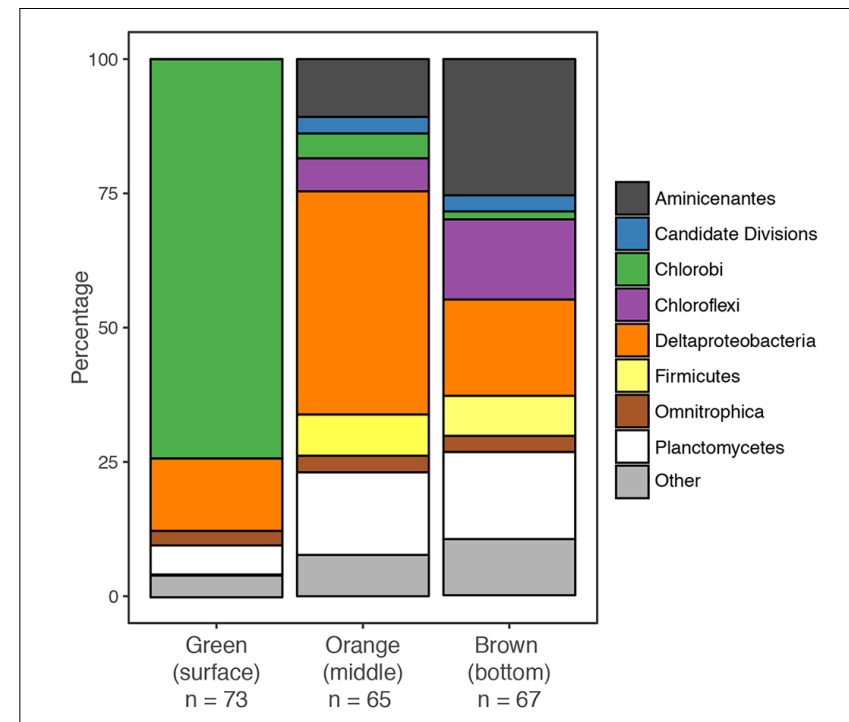

FIGURE 4 | Community structure of individual mat layers based on bacterial 16S rRNA clone libraries.

spectrum, but had different RTs ranging from 11.2 to $16.9 \mathrm{~min}$. Besides BChl $e$ we did not detect any type of BChl or chlorophyll.

\section{Low-Light Dependent Uptake of ${ }^{13} \mathrm{C}$-Labeled DIC and Acetate}

In situ incubation with ${ }^{13} \mathrm{C}$-labeled DIC or acetate revealed lightdependent uptake of inorganic and organic carbon (at $0.27 \mu \mathrm{mol}$ photons $\mathrm{m}^{-2} \mathrm{~s}^{-1}$ ) by surface-layer mat bacteria. Light dependent uptake of DIC was sevenfold higher than uptake of acetate (Figure 6). Dark uptake rates of both acetate and DIC were considerably lower.

Single-cell net phototrophic uptake rates were determined from estimated cell numbers per incubation vial and experimentally determined carbon uptake rates (DIC: $7.1 \times 10^{-9}$ nmol C cell ${ }^{-1} \mathrm{~h}^{-1}$; acetate: $1.2 \times 10^{-10} \mathrm{nmol}$ $\mathrm{C}$ cell $\left.{ }^{-1} \mathrm{~h}^{-1}\right)$. Assuming that the mat surface is homogeneously covered by active photoautotrophic cells, we used single-cell rates to estimate an in situ autotrophic carbon fixation rate of $14.5 \mathrm{nmol} \mathrm{C} \mathrm{cm} \mathrm{cm}^{-2} \mathrm{~d}^{-1}$. If photosynthetic sulfide oxidation strictly proceeded according to Eq. 1, this corresponded to a phototrophic sulfide oxidation rate of $29.0 \mathrm{nmol} \mathrm{S} \mathrm{cm}-2$ $\mathrm{d}^{-1}$. The photosynthetic quantum yield under experimental conditions was calculated from the photon flux of light between 475-530 nm $\left(1.93 \times 10^{-5} \mu \mathrm{mol}\right.$ photons $\left.\mathrm{m}^{-2} \mathrm{~s}^{-1}\right)$ per total incubated cell surface area $\left(7.16 \times 10^{-5} \mathrm{~m}^{2}\right.$ per vial, see section "Isotope Incubations for Process Rate Determination") and the ${ }^{13} \mathrm{C}$-uptake rate per incubation vial $\left(0.83 \mathrm{nmol} \mathrm{C}\right.$ vial $\left.{ }^{-1} \mathrm{~h}^{-1}\right)$ resulting in 0.056 moles of inorganic carbon fixed per mole photon reaching the incubated cells. This only takes into consideration the part of the light spectrum $(475-530 \mathrm{~nm})$ that can be absorbed by the photopigments found in the mats (Figure 5 and see section "Discussion"). We assumed that all cells in the incubation vials were photoautotrophic GSB, that there was no shading and that all photons hitting a cell 


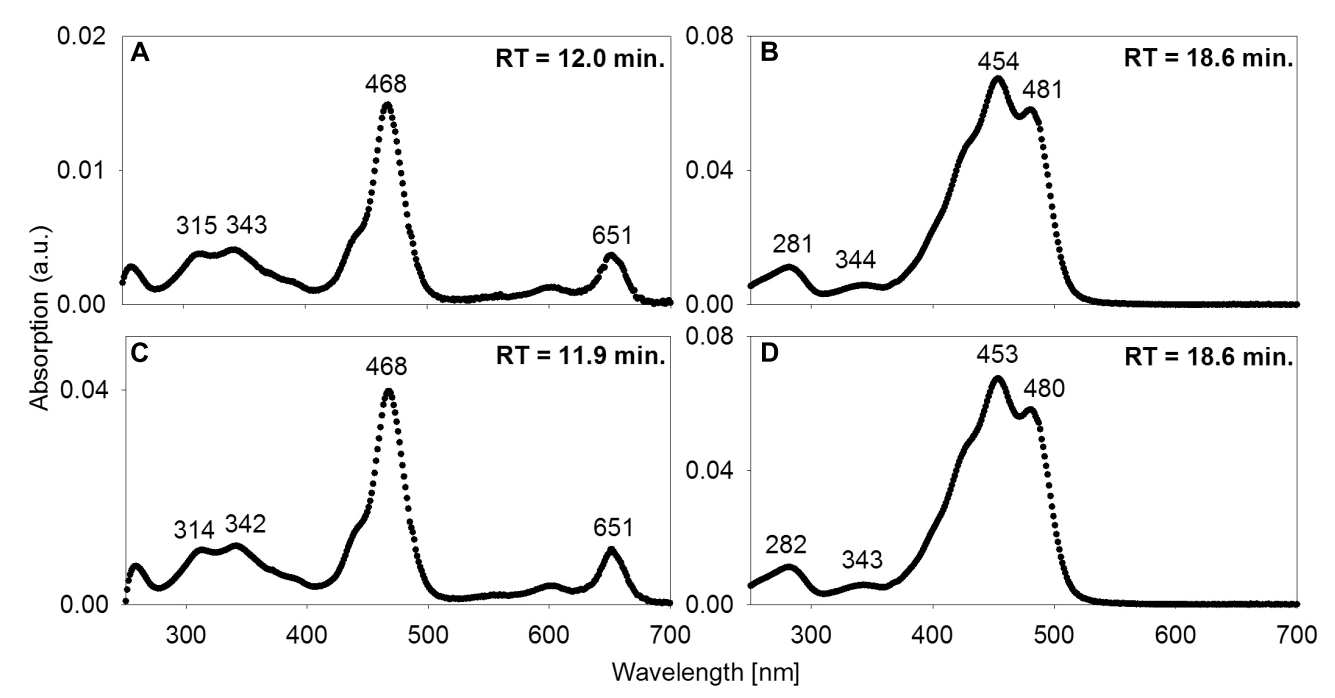

FIGURE 5 | Absorption spectra of acetone-extracted photosynthetic pigments. (A,B) from the mats; (C,D) and from freeze-dried culture material of low-light-adapted Prosthecochloris phaeobacteroides BS1 strain from the Black Sea. Wavelengths [nm] of absorption maxima are indicated as well as RT in the HPLC column.
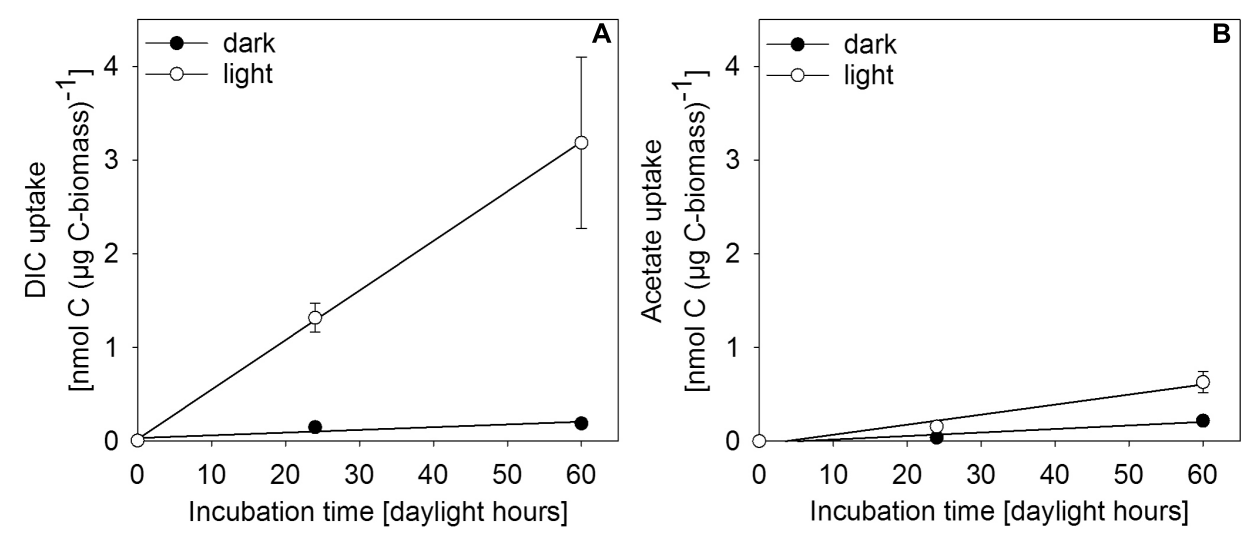

FIGURE 6 | Incorporation of (A) DIC and (B) acetate as uptake per carbon biomass of upper-layer mat material during incubation in in situ water at 30 m depth in the center of $\mathrm{MBH}$. Dark controls were shielded from light during incubation. Error bars indicate standard deviation of the mean of parallel incubations ( $n=3$ ).

were absorbed. Depending on absorption efficiency and the share of non-photoautotrophic cells in our incubation vials, the photoautotrophic quantum yield was likely higher than our rough estimate of $0.056 \mathrm{~mol} \mathrm{C}$ (mol photon) $)^{-1}$.

\section{Fe-S-Biogeochemistry}

Sulfate reduction rates in 10 mat cores were typically very low, but highly variable between mat samples and highly heterogeneous within each core (Figure 7F). SRRs in the majority of subsamples fell below the detection limit. No consistent trend with depth within the mat was observed. The vertically integrated areal fluxes of sulfide caused by sulfate reduction determined in all ten samples were highly variable. Their average $\left(30.4 \mathrm{nmol} \mathrm{S} \mathrm{cm}{ }^{-2}\right.$ $\mathrm{d}^{-1}$ ) was in the range of sulfide consumption by anoxygenic photosynthesis we found in the mats. Sulfate was available in large amounts throughout the mat (Figure 7C). More than the other analyzed Fe-S parameters, $S^{0}$ concentration showed a consistent vertical distribution within most mat core replicates. The highest $S^{0}$ concentrations (average \pm standard deviation: $0.12 \pm 0.06 \mu \mathrm{mol} \mathrm{S} \mathrm{cm}{ }^{-3}$ ) were found in the top $0.25 \mathrm{~cm}$ decreasing to an average of $0.02 \pm 0.01 \mu \mathrm{mol} \mathrm{S} \mathrm{cm}^{-3}$ below $0.5 \mathrm{~cm}$ below the mat surface (Figure 7E). This indicated influx of $\mathrm{S}^{0}$ produced by aerobic sulfide oxidation in the halo-chemocline or in situ production by anoxygenic phototrophs and removal by $S^{0}$ reduction or disproportionation below the photic layer.

Next to sulfate, dithionite reactive iron $(\approx \mathrm{Fe}(\mathrm{III})+\mathrm{FeS})$ and CRS $\left(=\mathrm{FeS}_{2}+\mathrm{S}^{0}\right)$ were by far the most abundant pools of iron and sulfur we found in the mats (Figure 7). High concentrations of CRS indicated that the mats were rich in pyrite given the relatively low concentrations of $\mathrm{S}^{0}$. FeS and $\mathrm{H}_{2} \mathrm{~S}$ were almost absent, as indicated by low AVS values (Figure 7A). Since its FeS component was negligible, the abundant dithionite reactive iron 

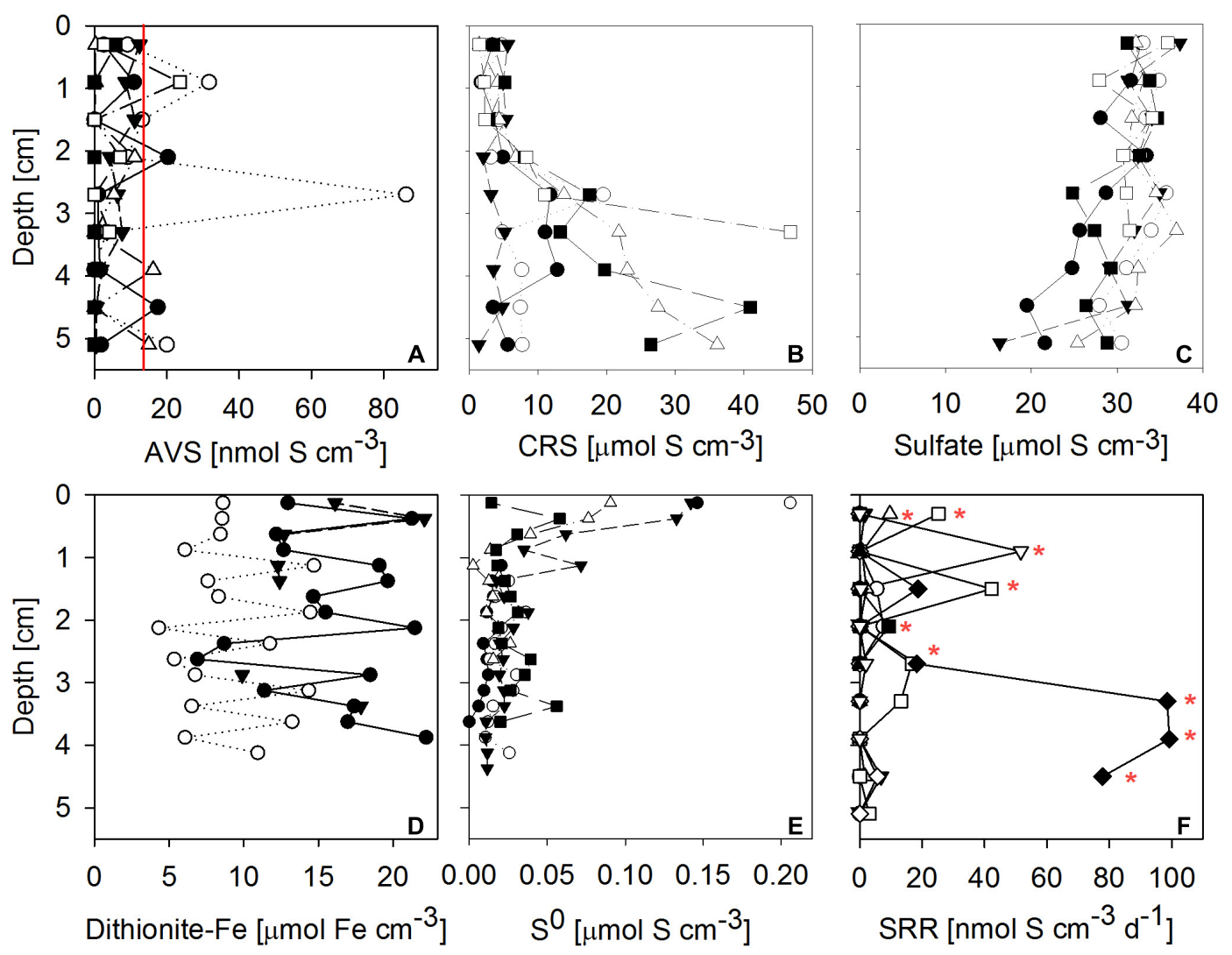

FIGURE 7 | Vertical profiles of Fe-S biogeochemical parameters through microbial mat cores. Different symbols identify replicate measurements from replicate mat cores. (A) Solid phase AVS ( = FeS + Fe $\mathrm{S}_{4}+\mathrm{H}_{2} \mathrm{~S} ; n=6$ replicate cores, the red line indicates detection limit); (B) solid phase CRS ( = FeS 2 + $\mathrm{S}^{0} ; n=6$ ); (C) porewater sulfate concentration $(n=6)$; (D) solid phase dithionite reactive iron $(\approx$ Fe(III) + FeS; $n=3)$; (E) solid phase + porewater $S^{0}$ concentrations $(n=5)$; (F) sulfate reduction rates (SRR; $n=10$, red stars indicate sulfate reduction rates above detection limit). AVS, CRS and sulfate concentrations were measured on the same cores, the remaining parameters were measured on independent cores.

largely consisted of oxidized iron [Fe(III)]. Fe(III) concentrations were in the same range as CRS concentrations. In some but not all samples, CRS showed a clear increase below $2 \mathrm{~cm}$ mat depth (Figure 7B). For dithionite reactive iron, no trend with depth could be identified.

\section{DISCUSSION}

\section{Extremely Low-Light-Adapted Anoxygenic Photosynthesis}

Our results show that bacteria in the mats of $\mathrm{MBH}$ perform anoxygenic photosynthesis under extremely low light conditions. Based on the mat color and on the abundance of 16S rRNA genes affiliated with GSB in clone libraries, it is likely that GSB are the dominating phylum in the upper layer (Figure 4). The single cluster of GSB we identified in MBH mats is closely related to the extremely low-light-adapted strain $P$. phaeobacteroides BS1 (Supplementary Figure S1) from the Black Sea chemocline (Marschall et al., 2010). Pigment analysis revealed the presence of $(\beta$-)isorenieratene in all layers and $\mathrm{BChl} e$ in the upper layers of the mat, which are the typical photopigments of brown-colored GSB including $P$. phaeobacteroides BS1 (Marschall et al., 2010). The $505 \mathrm{~nm}$ in vivo absorption maximum of the brown-colored and extremely low-light-adapted Chlorobium strain MN1 (Overmann et al., 1992) coincided with the part of the spectrum between $475 \mathrm{~nm}$ and $530 \mathrm{~nm}$ that is relatively abundant at the cave wall (Figure 3B). Incubation with ${ }^{13} \mathrm{C}$-labeled compounds directly demonstrated light-dependent carbon uptake by mat microorganisms under close-to in situ irradiance ( $\leq 0.27 \mu \mathrm{mol}$ photons $\left.\mathrm{m}^{-2} \mathrm{~s}^{-1}\right)$. Photoautotrophic fixation of DIC was considerably more efficient than photoheterotrophic incorporation of acetate (Figure 6). Indeed, GSB can be mixotrophic regarding their utilized carbon sources (Feng et al., 2010; Tang and Blankenship, 2010). Given that all GSB sequences in our clone libraries formed a single cluster (Supplementary Figure S1), it is likely that heterotrophic and autotrophic phototrophy were performed by the same population.

Anoxygenic photosynthesis under similarly extreme low-light conditions as observed in $\mathrm{MBH}$ has previously been described by phylogenetically similar bacteria in the Black Sea chemocline. Photoautotrophic activity at light intensities as low as $0.055 \mu \mathrm{mol}$ photons $\mathrm{m}^{-2} \mathrm{~s}^{-1}$ in situ (Marschall et al., 2010) and as low as 
$0.015 \mu$ mol photons $\mathrm{m}^{-2} \mathrm{~s}^{-1}$ in laboratory cultures (Manske et al., 2005) was reported. Maximum scalar irradiance, measured on a sunny December day shortly after noon at the cave wall next to the $\mathrm{MBH}$ mats, was $0.084 \mu \mathrm{mol}$ photons $\mathrm{m}^{-2} \mathrm{~s}^{-1}$ (Figure 3). Since light is strongly attenuated with depth in microbial mats (Kühl et al., 1997), cells in deeper layers will experience even less light and might display extreme phototrophic quantum efficiencies. The photoautotrophic quantum yield observed during incubation of $\mathrm{MBH}$ mat cells of $0.056 \mathrm{~mol} \mathrm{C}$ (mol photons $)^{-1}$ was low compared to previously reported values in GSB (Brune, 1989). However, we likely underestimated the real quantum yield in our assumption that all cells in our experimental vials were photoautotrophs which absorbed $100 \%$ of available photons of adequate wavelength. Also, sulfide and light in situ were much lower than under the experimental conditions these quantum yields were measured. We would expect to find a much higher quantum yield under more controlled experimental conditions.

\section{Light Harvesting Niches}

The irradiance maxima in the UV ( $<400 \mathrm{~nm}$ ) and blue-green $(475-530 \mathrm{~nm}$ ) parts of the in situ light spectrum (Figure 3B) can be understood from the absorption coefficient of water, which has its minimum between 400 and $500 \mathrm{~nm}$ (Sogandares and Fry, 1997). The observed shift toward short wavelengths measured at $30 \mathrm{~m}$ depth is thus explained by physical attenuation in the overlying water column (Sogandares and Fry, 1997), making the $\mathrm{MBH}$ light spectrum resemble spectra from other oligotrophic water columns (Stomp et al., 2007). Oxygenic photosynthesis in the upper water column is the most plausible explanation for the observed minimum between 400 and $475 \mathrm{~nm}$ in our light spectra (Figure 3B) as it coincides with the short-wavelength absorption peak of Chlorophylls $a / b(430 / 460 \mathrm{~nm})$. This zone is probably located above $17 \mathrm{~m}$ depth, where relatively rapid light attenuation with depth was observed (Figure 2A) and dissolved organic carbon concentration was highest.

A typical strategy of anoxygenic phototrophs from mats at shallow water depths is to harvest near-IR light of wavelengths longer than the long-wavelength maxima of chlorophylls $a / b$ (Overmann et al., 1991). In deeper water columns including $\mathrm{MBH}$, long-wavelength light is attenuated, thus phototrophic mat bacteria must make use of the remaining blue-green light (around $500 \mathrm{~nm}$ ) and under extreme light limitation might be forced to use the UV-A (320-400 nm) parts of the spectrum. The low-light-adapted Chlorobium strain MN1 with the same photosynthetic pigment setup we found in $\mathrm{MBH}$ mats [BChl $e$ and $(\beta)$-isorenieratene] has an in vivo absorption maximum around $500 \mathrm{~nm}$ (Overmann et al., 1992), which is attributable to BChl e (Cox et al., 1998; Glaeser et al., 2002).

Bacteriochlorophyll $e$ also has an ex vivo absorption maximum around $340 \mathrm{~nm}$ within the UV-A part of the light spectrum (Figures 5A,C). UV light is commonly thought to be damaging rather than utilizable for phototrophic organisms due to its high energy content (Post and Larkum, 1993; Moisan and Mitchell, 2001; Xue et al., 2005). However, several studies demonstrated that UV-A light can enhance oxygenic photosynthesis (Helbling et al., 2003; Gao et al., 2007; Xu and Gao, 2010). Since irradiance $<400 \mathrm{~nm}$ constitutes the most abundant source of light energy in their environment, anoxygenic phototrophs in $\mathrm{MBH}$ mats may be able to harvest UV-A light for anoxygenic photosynthesis. This hypothesis remains to be tested in future work.

\section{Fe-S-Biogeochemistry: The MBH Mat as Net Sulfide Sink}

\section{The Role of Phototrophic Sulfide Oxidation}

Low sulfide (as indicated by AVS) and large amounts of pyrite$S$ (as indicated by high CRS and low $\mathrm{S}^{0}$ ) suggest the role of the mats as sulfide sinks (Figure 7). Due to the extreme light limitation, it is questionable whether phototrophic sulfide oxidation can play a quantitatively significant role in $\mathrm{MBH}$ sulfur biogeochemistry. Our rough estimates of sulfide fluxes from phototrophic sulfide oxidation were in the range of the mean areal SRRs (both approximately $30 \mathrm{nmol} \mathrm{S} \mathrm{cm}{ }^{-2} \mathrm{~d}^{-1}$ ), suggesting other, quantitatively more important, processes are causing the mats to be sulfide sinks.

\section{The Role and Provenance of Fe-Oxides}

Surprisingly large amounts of Fe-oxides were likely the main source of oxidation power in the mats. Fe(III) and CRS concentrations were in the range of values from coastal North Sea sediments (Thamdrup et al., 1994; Holmkvist et al., 2011) and sediments around Dvurechenskii mud volcano, where Lichtschlag et al. (2013) reported sulfide oxidation by $\mathrm{Fe}$ - or Mn-oxides. Fe-oxides can react with sulfide to form FeS and $\mathrm{S}^{0}$ (Jørgensen and Nelson, 2004):

$$
3 \mathrm{H}_{2} \mathrm{~S}+2 \mathrm{FeOOH} \rightarrow \mathrm{S}^{0}+2 \mathrm{FeS}+4 \mathrm{H}_{2} \mathrm{O}
$$

The reaction of $S^{0}$ with sulfide yields polysulfide $\left(S_{x}{ }^{2-}\right)$, which can enhance the rate of pyrite $\left(\mathrm{FeS}_{2}\right)$ formation (Luther, 1991):

$$
\mathrm{FeS}+\mathrm{S}_{\mathrm{x}}{ }^{2-} \rightarrow \mathrm{FeS}_{2}+\mathrm{S}_{(\mathrm{x}-1)}{ }^{2-}
$$

A variety of reaction types for pyrite formation by reaction of sulfide with $\mathrm{Fe}(\mathrm{III})$-minerals, $\mathrm{Fe}^{2+}$ and $\mathrm{FeS}$ are possible (discussed in Holmkvist et al., 2011). Low concentrations of AVS compared to pyrite-S in the mat suggested that the FeS quickly reacts further to form pyrite (Eq. 3), which is quite stable under reduced conditions (Fossing and Jørgensen, 1990).

The origin of very abundant Fe(III) in the mats might be dust from the Sahara, particularly the Sahel zone (Shinn et al., 2000). This Fe-containing dust was deposited episodically during climatic fluctuations (Swart et al., 2010) on the land surface, on forming soils, and in air-filled caves, which later flooded to become anchialine caves. Millimeter- to centimeter-thick red dust layers, filling crevices and niches in flooded passages, have been observed by cave divers including B. Kakuk (personal communication). Bottrell et al. (1991) found large amounts of pyrite in the cave wall of another Bahamian blue hole. Iron reducing bacteria may have settled on such iron rich dust features in the cave wall of $\mathrm{MBH}$ and initialized formation of the mats. Initial input of $\mathrm{Fe}$ (III) from the bottom of the mats 
in combination with continuous iron settling on the mats from the water column may explain the constant distribution of large amounts of Fe(III) throughout the mat.

Additionally, Fe(III) may be produced by iron oxidizing anoxygenic phototrophs (Widdel et al., 1993) on the mat surface. Photoferrotrophs may take up dissolved $\mathrm{Fe}^{2+}$ from the water column or as the product of reductive dissolution of iron from the limestone rock and also prevent the diffusive loss of $\mathrm{Fe}^{2+}$ produced during pyrite formation (Holmkvist et al., 2011), making the mats effective traps for dissolved and colloidal iron. This would create a niche for iron reducers, which would close the iron cycle. However, evidence for photoferrotrophy in $\mathrm{MBH}$ mats is lacking. Chlorobium phaeoferrooxidans is the first known photoferrotrophic GSB containing BChl $e$, which could theoretically enable it to harvest the part of the light spectrum available at the $\mathrm{MBH}$ cave wall (Llirós et al., 2015; Crowe et al., 2017). The MBH GSB cluster was neither affiliated with $C$. phaeoferrooxidans nor the other known or putative photoferrotrophic GSB Chlorobium ferrooxidans and Chlorobium luteolum (Supplementary Figure S1; Heising et al., 1999; Frigaard and Bryant, 2008).

\section{Shortages of Organic Carbon and Sulfide}

Despite the presence of photosynthesizing bacteria, $\mathrm{MBH}$ mats appear limited in chemical reductants, notably sulfide and organic carbon. Even if surplus organic carbon is produced in anoxygenic photosynthesis, it may be unavailable for organoheterotrophs, because it can be used by photoheterotrophs (Figure 6B). Low concentrations of nutrients and dissolved organic matter in the overlying water column were well below average lake water concentrations (Chen et al., 2015). Organic carbon shortage within the mats is suggested by low to undetectable SRRs despite high concentrations of sulfate (Figure 7F), which were much lower than in similar microbial mats and biofilms (Canfield and Des Marais, 1991; Kühl and Jørgensen, 1992; Visscher et al., 1992). A locally restricted anomaly of elevated SRRs in one sample may be explained by a pocket of high organic carbon, perhaps from sunken terrestrial material (Figure 7F).

Due to the low SRRs within the mats, the primary source of sulfide to the mats is from the water column. Vertical profiles of sulfide concentration (Figure 2) suggested small sources of sulfide from the bottom of the blue hole and in the halo-chemocline, where sulfate reduction has previously been observed in another Bahamian blue hole (Bottrell et al., 1991). Sulfate reduction in the halo-chemocline may be more active than in the mats due to better access to organic carbon from oxygenic phototrophy in the oxic water column, and potential anoxygenic phototrophy in the halo-chemocline (Macalady et al., 2010).

$\delta$-Proteobacterial sulfate reducers and other heterotrophs seem to be abundant in the mats but their activity limited by organic carbon availability. Sulfate reduction may also experience competition for the scarce organic carbon by anoxygenic photoheterotrophy and iron reduction. While a majority of

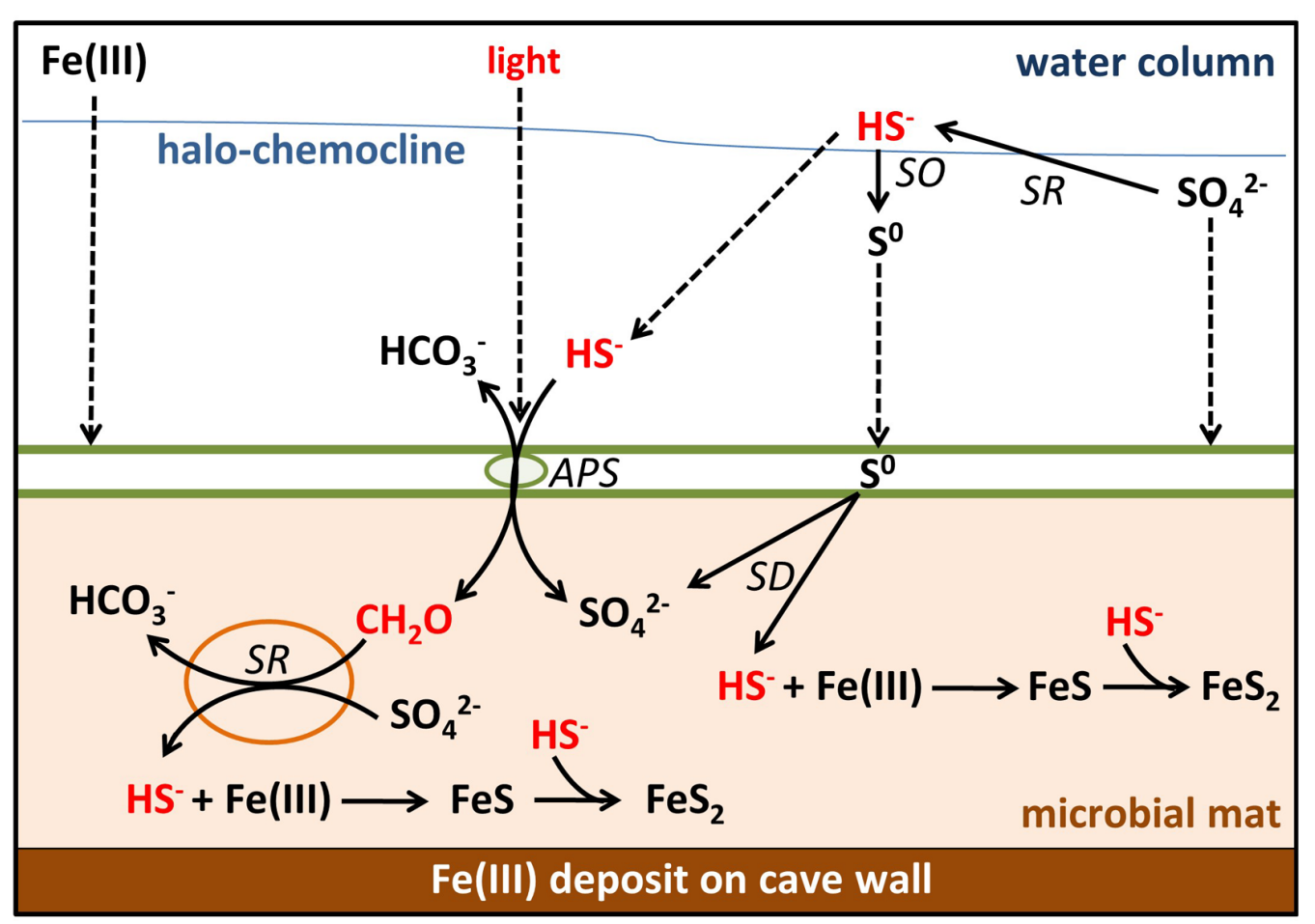

FIGURE 8 | Sulfur, carbon, and iron biogeochemical cycling in the MBH microbial mat. Biotic processes are labeled SD ( ${ }^{0}$ disproportionation), SO (sulfide oxidation), SR (sulfate reduction), and APS (anoxygenic photosynthesis). Remaining processes are abiotic. Parameters limiting the sulfur cycle in the mat are marked with red color. Dashed arrows indicate input by sinking or diffusion from outside the mats. Green spheres = GSB; orange spheres $=\delta$-Proteobacteria. 
the $\delta$-Proteobacteria in our clone libraries were affiliated with Desulfobacteraceae and Syntrophobacteraceae (Supplementary Figure S2), indicating that they are likely sulfate reducers (Kuever, $2014 a, b)$, the affiliation of several other clones within the $\delta$ Proteobacteria was unresolved and leaves room to speculate that they might reduce iron (Lovley et al., 2004) or disproportionate $S^{0}$ (Thamdrup et al., 1993). Generally, the community composition of the orange and brown portions of the $\mathrm{MBH}$ mats was defined by groups ( $\delta$-Proteobacteria, Chloroflexi, Planctomycetes, Aminicenantes, and Omnitrophica; Figure 2) that have previously been linked to heterotrophic and fermenting carbon degradation in similar environments (Inagaki et al., 2006; Gies et al., 2014). In $\mathrm{MBH}$ mats, the activity of these heterotrophic bacteria must be assumed to be limited by the scarce organic carbon. We therefore propose that the mats have grown slowly but largely undisturbed over long time scales - a hypothesis that warrants future research.

\section{The Sulfur Cycle Was Slow in the Presence of Iron and Low Organic Carbon}

Despite the presence of large amounts of sulfate, sulfur cycling within the mats was slowed down due to organic carbon shortage and the accumulations of $\mathrm{Fe}(\mathrm{III})$. Anoxygenic phototrophs were limited by light and probably also by sulfide, given slow production by sulfate reduction and competition by abiotic precipitation indicated by the pyrite accumulations. Therefore, mat-internal primary production was low and so was organic matter input from the oligotrophic water column. Low SRRs can thus be explained by organic carbon limitation.

In oxic shallow-water environments light energy can enable a phototrophic community to supply the deeper anoxic layers of a microbial mat with enough organic carbon to enable sulfate reduction to compete with FeS formation even in the presence of considerable amounts of iron (Wieland et al., 2005). If iron is present in anoxic environments under oligotrophic and lightlimited conditions, sulfur cycling is slowed down considerably. In principle, this shortage in reductants would provide a niche for oxygenic photosynthesis, but the $\mathrm{MBH}$ light level is too low for the high energy water splitting reaction. High influx of organic carbon or sulfide would be needed to stimulate more active sulfur cycling in low-light mats.

\section{Conclusions and Implications}

The biogeochemistry of $\mathrm{MBH}$ is characterized by limitation of energy sources like light and organic carbon. This leads to slow rates of anoxygenic photosynthesis and heterotrophic processes like sulfate reduction (Figure 8). Low SRRs and AVS concentrations falsified our hypothesis of the mats functioning as a net sulfide source. Instead, high concentrations of pyrite$S$ indicated abiotic sulfide scavenging as the mechanism responsible for making the mats a net sulfide sink. The role of very abundant $\delta$-Proteobacteria in clone libraries has yet to be finally resolved, but most of them appear to be sulfate reducers whose activity is low due to organic carbon limitation.

Most sulfide produced by any in situ sulfate reduction or diffusing into the mat from the water column will be scavenged by abundant iron oxides rather than oxidized by light-limited anoxygenic phototrophs. Thus, little organic carbon is produced in situ, preventing sulfate reduction or limiting it to very low rates. In the absence of significant external input of sulfide, light and organic carbon, the sulfur cycling in these mats is slowed down. Further investigations of these mechanisms may ultimately help to understand the creation of ferruginous conditions in the presence of sulfate which is relevant for Proterozoic ocean water columns. Ferruginous conditions prevailed in the Meso(Planavsky et al., 2011) and Neoproterozoic ocean (Canfield et al., 2008) despite the presence of approximately $1 \mathrm{mM}$ sulfate (Canfield and Farquhar, 2009), which requires limitation of sulfate reduction for example by organic carbon delivery (Johnston et al., 2010; Planavsky et al., 2011).

Despite extreme light limitation, anoxygenic photosynthesis by GSB could be detected. Barely explored traits in anoxygenic photosynthesis may be hypothesized based on our data and demand further investigation including the possibility of UV-A utilization by low-light-adapted GSB. Our data show that phylogenetically very similar organisms using the same photopigment setup are responsible for anoxygenic photosynthesis in two contrasting habitats with the lowest irradiance at which photosynthesis has been reported: as planktonic cells in the Black Sea chemocline (Overmann et al., 1992) and associated as a microbial mat on the cave wall of $\mathrm{MBH}$. Their photopigments $\mathrm{BChl} e$ and $(\beta$-)isorenieratene in combination with $16 \mathrm{~S}$ rRNA from known brown-colored GSB species are therefore promising biomarkers for low-light anoxygenic photosynthesis in a range of modern and ancient environments.

\section{AUTHOR CONTRIBUTIONS}

SH, JM, DdB, and AF contributed to the design of the study and the experiments. VM designed and built the custom-made light sensor. SH planned and $\mathrm{SH}, \mathrm{BK}$, and JM led the field work to which $\mathrm{TH}$ contributed. $\mathrm{SH}$ did the main laboratory work, supported by AF and JK. RMR contributed a subset of the data (clone libraries and carbon concentrations) from her work in collaboration with JM and their additional exploratory data helped to guide this study. SH, DdB, JM, AF, JK, and TH contributed to data evaluation and interpretation. $\mathrm{SH}$ was the main author of the manuscript. SH, DdB, JM, and JK developed the intellectual content of the manuscript, to which TH and AF contributed. All authors contributed to manuscript revision and approved the submitted version.

\section{FUNDING}

This study was funded by the Max-Planck Institute for Marine Microbiology, the National Science Foundation (EAR-0525503 to JM), the NASA Astrobiology Institute (PSARC, NNA04CC06A to JM), a Lewis and Clark Fund for Exploration and Field Research in Astrobiology Fellowship (to RM), a National Science Foundation Graduate Research Fellowship Travel Grant (to RM), 
the Canadian Excellence Research Chair in Oceanography (SH), and the NASA Astrobiology Institute Postdoctoral Program (TH).

\section{ACKNOWLEDGMENTS}

We are indebted to Jörg Overmann and his group at DSMZ Braunschweig for providing freeze-dried Chlorobium culture material. We thank Marit van Erk for the $S^{0}$ analyses, Arjun Chennu, Tim Ferdelman, Mohammad al-Najjar, and Gaute Lavik for the expert advice on methodology, as well as Martina Alisch, Gabriele Klockgether, and all MPI Microsensor TAs for helping with sample analysis and microsensor preparation. Furthermore, we thank Tomas Wilkop and Manfred Schlösser for their

\section{REFERENCES}

Al-Najjar, M. A., de Beer, D., Kühl, M., and Polerecky, L. (2012). Light utilization efficiency in photosynthetic microbial mats. Environ. Microbiol. 14, 982-992. doi: 10.1111/j.1462-2920.2011.02676.x

Altschul, S. F., Madden, T. L., Schäffer, A. A., Zhang, J., Zhang, Z., Miller, W., et al. (1997). Gapped BLAST and PSI-BLAST: a new generation of protein database search programs. Nucleic Acids Res. 25, 3389-3402. doi: 10.1093/nar/25.17.3389

Borrego, C. M., Arellano, J. B., Abella, C. A., Gillbro, T., and Garcia-Gil, J. (1999). The molar extinction coefficient of bacteriochlorophyll e and the pigment stoichiometry in Chlorobium phaeobacteroides. Photosynth. Res. 60, 257-264. doi: 10.1023/A:1006230820007

Borrego, C. M., and Garcia-Gil, L. J. (1994). Separation of bacteriochlorophyll homologues from green photosynthetic sulfur bacteria by reversed-phase HPLC. Photosynth. Res. 41, 157-164. doi: 10.1007/BF02184156

Bottrell, S. H., Smart, P. L., Whitaker, F., and Raiswell, R. (1991). Geochemistry and isotope systematics of sulphur in the mixing zone of Bahamian blue holes. Appl. Geochem. 6, 97-103. doi: 10.1016/0883-2927(91)90066-X

Brune, D. C. (1989). Sulfur oxidation by phototrophic bacteria. Biochim. Biophys. Acta 975, 189-221. doi: 10.1016/S0005-2728(89)80251-8

Canfield, D. E., and Des Marais, D. J. (1991). Aerobic sulfate reduction in microbial mats. Science 251, 1471-1473. doi: 10.1126/science.11538266

Canfield, D. E., and Farquhar, J. (2009). Animal evolution, bioturbation, and the sulfate concentration of the oceans. Proc. Natl. Acad. Sci. U.S.A. 106, 8123-8127. doi: 10.1073/pnas.0902037106

Canfield, D. E., Poulton, S. W., Knoll, A. H., Narbonne, G. M., Ross, G., Goldberg, T., et al. (2008). Ferruginous conditions dominated later neoproterozoic deep-water chemistry. Science 321, 949-952. doi: 10.1126/science.1154499

Chen, M., Zeng, G., Zhang, J., Xu, P., Chen, A., and Lu, L. (2015). Global landscape of total organic carbon, nitrogen and phosphorus in lake water. Sci. Rep. 5:15043. doi: $10.1038 /$ srep 15043

Cline, J. D. (1969). Spectrophotometric determination of hydrogen sulfide in natural waters. Limnol. Oceanogr. 14, 454-458. doi: 10.4319/lo.1969.14.3.0454

Cornwell, J. C., and Morse, J. W. (1987). The characterization of iron sulfide minerals in anoxic marine sediments. Mar. Chem. 22, 193-206. doi: 10.1016/ 0304-4203(87)90008-9

Cox, R. P., Miller, M., Aschenbrücker, J., Ma, Y.-Z., and Gillbro, T. (1998). “The role of bacteriochlorophyll $e$ and carotenoids in light harvesting in brown-colored green sulfur bacteria," in Photosynthesis: Mechanisms and Effects, ed. G. Garab (Amsterdam: Springer), 149-152.

Crowe, S. A., Hahn, A. S., Morgan-Lang, C., Thompson, K. J., Simister, R. L., Llirós, M., et al. (2017). Draft genome sequence of the pelagic photoferrotroph Chlorobium phaeoferrooxidans. Genome Announc. 5:e01584-16. doi: 10.1128/ genomeA.01584-16

Crowe, S. A., Maresca, J. A., Jones, C., Sturm, A., Henny, C., Fowle, D. A., et al. (2014). Deep-water anoxygenic photosythesis in a ferruginous chemocline. Geobiology 12, 322-339. doi: 10.1111/gbi.12089 support in preparing the field excursion, and the MPI Electronics and Mechanics workshops for their technical ingenuity. Sean Crowe provided valuable inspiration for Proterozoic Ocean implications. Three anonymous reviewers from an unsuccessful previous submission of the manuscript gave valuable suggestions for improvement. SH feels indebted to the Max-Planck society and the MarMic program for the excellent scientific training and funding.

\section{SUPPLEMENTARY MATERIAL}

The Supplementary Material for this article can be found online at: https://www.frontiersin.org/articles/10.3389/fmicb. 2018.00858/full\#supplementary-material

Darriba, D., Taboada, G. L., Doallo, R., and Posada, D. (2012). jModelTest 2: more models, new heuristics and parallel computing. Nat. Methods 9:772. doi: 10.1038/nmeth.2109

Engel, A. S., Porter, M. L., Stern, L. A., Quinlan, S., and Bennett, P. C. (2004). Bacterial diversity and ecosystem function of filamentous microbial mats from aphotic (cave) sulfidic springs dominated by chemolithoautotrophic “Epsilonproteobacteria". FEMS Microbiol. Ecol. 51, 31-53. doi: 10.1016/j.femsec. 2004.07.004

Feng, X., Tang, K.-H., Blankenship, R. E., and Tang, Y. J. (2010). Metabolic flux analysis of the mixotrophic metabolisms in the green sulfur bacterium Chlorobaculum tepidum. J. Biol. Chem. 285, 39544-39550. doi: 10.1074/jbc. M110.162958

Fossing, H., and Jørgensen, B. B. (1989). Measurement of bacterial sulfate reduction in sediments: evaluation of a single-step chromium reduction method. Biogeochemistry 8, 205-222. doi: 10.1007/BF00002889

Fossing, H., and Jørgensen, B. B. (1990). Oxidation and reduction of radiolabeled inorganic sulfur compounds in an estuarine sediment, Kysing Fjord, Denmark. Geochim. Cosmochim. Acta 54, 2731-2742. doi: 10.1016/0016-7037(90)90 008-9

Frigaard, N.-U., and Bryant, D. A. (2008). "Genomic insights into the sulfur metabolism of phototrophic green sulfur bacteria," in Sulfur Metabolism in Phototrophic Organisms. Advances in Photosynthesis and Respiration, eds R. Hell, C. Dahl, D. Knaff, and T. Leustek (Dordrecht: Springer), 337-355. doi: 10.1007/978-1-4020-6863-8_17

Fuciman, M., Chábera, P., Župèanová, A., Høíbek, P., Arellano, J. B., Vácha, F., et al. (2010). Excited state properties of aryl carotenoids. Phys. Chem. Chem. Phys. 12, 3112-3120. doi: 10.1039/B921384H

Gao, K., Wu, Y., Li, G., Wu, H., Villafane, V. E., and Helbling, E. W. (2007). Solar $\mathrm{UV}$ radiation drives $\mathrm{CO}_{2}$ fixation in marine phytoplankton: a double-edged sword. Plant Physiol. 144, 54-59. doi: 10.1104/pp.107.098491

Gies, E. A., Konwar, K. M., Beatty, J. T., and Hallam, S. J. (2014). Illuminating microbial dark matter in meromictic Sakinaw Lake. Appl. Environ. Microbiol. 80, 6807-6818. doi: 10.1128/AEM.01774-14

Glaeser, J., Bañeras, L., Rütters, H., and Overmann, J. (2002). Novel bacteriochlorophyll e structures and species-specific variability of pigment composition in green sulfur bacteria. Arch. Microbiol. 177, 475-485. doi: 10.1007/s00203-002-0416-4

Gloe, A., Pfennig, N., Brockmann, H. Jr., and Trowitzsch, W. (1975). A new bacteriochlorophyll from brown-colored Chlorobiaceae. Arch. Microbiol. 102, 103-109. doi: 10.1007/BF00428353

Gonzalez, B. C., Iliffe, T. M., Macalady, J. L., Schaperdoth, I., and Kakuk, B. (2011). Microbial hotspots in anchialine blue holes: initial discoveries from the Bahamas. Hydrobiologia 677, 149-156. doi: 10.1007/s10750-011-0932-9

Griffin, B. M., Schott, J., and Schink, B. (2007). Nitrite, an electron donor for anoxygenic photosynthesis. Science 316:1870. doi: 10.1126/science.1139478

Halm, H., Lam, P., Ferdelman, T. G., Lavik, G., Dittmar, T., LaRoche, J., et al. (2012). Heterotrophic organisms dominate nitrogen fixation in the South Pacific Gyre. ISME J. 6, 1238-1249. doi: 10.1038/ismej.2011.182 
Hansen, H. P., and Koroleff, F. (2009). "Determination of nutrients," in Methods of Seawater Analysis, eds K. Grasshoff, K. Kremling, and M. Ehrhardt (Weinheim: Verlag Chemie), 159-228.

Hauska, G., Schoedl, T., Remigy, H., and Tsiotis, G. (2001). The reaction center of green sulfur bacteria. Biochim. Biophys. Acta 1507, 260-277. doi: 10.1016/ S0005-2728(01)00200-6

Heising, S., Richter, L., Ludwig, W., and Schink, B. (1999). Chlorobium ferrooxidans sp. nov., a phototrophic green sulfur bacterium that oxidizes ferrous iron in coculture with a "Geospirillum" sp. strain. Arch. Microbiol. 172, 116-124. doi: $10.1007 /$ s002030050748

Helbling, E. W., Gao, K., Gonçalves, R. J., Wu, H., and Villafañe, V. E. (2003). Utilization of solar UV radiation by coastal phytoplankton assemblages off SE China when exposed to fast mixing. Mar. Ecol. Prog. Ser. 259, 59-66. doi: 10.3354/meps259059

Holmkvist, L., Ferdelman, T. G., and Jørgensen, B. B. (2011). A cryptic sulfur cycle driven by iron in the methane zone of marine sediment (Aarhus Bay, Denmark). Geochim. Cosmochim. Acta 75, 3581-3599. doi: 10.1016/j.gca.2011. 03.033

Iliffe, T. M. (2000). "Anchialine cave ecology," in Ecosystems of the World: Subterranean Ecosystems, eds H. Wilkens, D. C. Culver, and W. F. Humphreys (Amsterdam: Elsevier), 59-76.

Imhoff, J. F., and Thiel, V. (2010). Phylogeny and taxonomy of Chlorobiaceae. Photosynth. Res. 104, 123-136. doi: 10.1007/s11120-009-9510-7

Inagaki, F., Nunoura, T., Nakagawa, S., Teske, A., Lever, M., Lauer, A., et al. (2006). Biogeographical distribution and diversity of microbes in methane hydratebearing deep marine sediments on the Pacific Ocean Margin. Proc. Natl. Acad. Sci. U.S.A. 103, 2815-2820. doi: 10.1073/pnas. 0511033103

Jørgensen, B. B. (1978). A comparison of methods for the quantification of bacterial sulfate reduction in coastal marine sediments. Geomicrobiol. J. 1, 11-27. doi: $10.1080 / 01490457809377721$

Jørgensen, B. B., and Nelson, D. C. (2004). Sulfide oxidation in marine sediments: geochemistry meets microbiology. Geol. Soc. Am. 379, 63-81. doi: 10.1130/08137-2379-5.63

Johnston, D. T., Poulton, S. W., Dehler, C., Porter, S., Husson, J., Canfield, D. E., et al. (2010). An emerging picture of Neoproterozoic ocean chemistry: insights from the Chuar Group, Grand Canyon, USA. Earth Planet. Sci. Lett. 290, 64-73. doi: 10.1016/j.epsl.2009.11.059

Kallmeyer, J., Ferdelman, T. G., Weber, A., Fossing, H., and Jørgensen, B. B. (2004). A cold chromium distillation procedure for radiolabeled sulfide applied to sulfate reduction measurements. Limnol. Oceanogr. Methods 2, 171-180. doi: 10.4319/lom.2004.2.171

Kostka, J. E., and Luther, G. W. (1994). Partitioning and speciation of solid phase iron in saltmarsh sediments. Geochim. Cosmochim. Acta 58, 1701-1710. doi: 10.1016/0016-7037(94)90531-2

Kuever, J. (2014a). "The family Desulfobacteraceae," in The Prokaryotes: Deltaproteobacteria and Epsilonproteobacteria, eds E. Rosenberg, E. F. DeLong, S. Lory, E. Stackebrandt, and F. Thompson (Berlin: Springer), 45-73.

Kuever, J. (2014b). "The family Syntrophobacteraceae," in The Prokaryotes: Deltaproteobacteria and Epsilonproteobacteria, eds E. Rosenberg, E. F. DeLong, S. Lory, E. Stackebrandt, and F. Thompson (Berlin: Springer), 289-299.

Kühl, M., and Jørgensen, B. B. (1992). Microsensor measurements of sulfate reduction and sulfide oxidation in compact microbial communities of aerobic biofilms. Appl. Environ. Microbiol. 58, 1164-1174.

Kühl, M., Lassen, C., and Revsbech, N. P. (1997). A simple light meter for measurements of PAR (400 to $700 \mathrm{~nm}$ ) with fiber-optic microprobes: application for $P$ vs $E_{0}$ (PAR) measurements in a microbial mat. Aquat. Microb. Ecol. 13, 197-207. doi: 10.3354/ame013197

Lau, M. C. Y., Aitchison, J. C., and Pointing, S. B. (2009). Bacterial community composition in thermophilic microbial mats from five hot springs in central Tibet. Extremophiles 13, 139-149. doi: 10.1007/s00792-008-0205-3

Letunic, I., and Bork, P. (2016). Interactive tree of life (iTOL) v3: an online tool for the display and annotation of phylogenetic and other trees. Nucleic Acids Res. 44, W242-W245. doi: 10.1093/nar/gkw290

Lichtschlag, A., Kamyshny, A., Ferdelman, T. G., and de Beer, D. (2013). Intermediate sulfur oxidation state compounds in the euxinic surface sediments of the Dvurechenskii mud volcano (Black Sea). Geochim. Cosmochim. Acta 105, 130-145. doi: 10.1016/j.gca.2012.11.025
Llirós, M., García-Armisen, T., Darchambeau, F., Morana, C., Triadó-Margarit, X., Inceoğlu, Ö., et al. (2015). Pelagic photoferrotrophy and iron cycling in a modern ferruginous basin. Sci. Rep. 5:13803. doi: 10.1038/srep13803

Lovley, D. R., Holmes, D. E., and Nevin, K. P. (2004). Dissimilatory Fe(III) and Mn(IV) reduction. Adv. Microb. Physiol. 49, 219-286. doi: 10.1016/S00652911(04)49005-5

Ludwig, W., Strunk, O., Westram, R., Richter, L., Meier, H., Buchner, A., et al. (2004). ARB: a software environment for sequence data. Nucleic Acids Res. 32, 1363-1371. doi: 10.1093/nar/gkh293

Luther, G. W. (1991). Pyrite synthesis via polysulfide compounds. Geochim. Cosmochim. Acta 55, 2839-2849. doi: 10.1016/0016-7037(91)90449-F

Macalady, J. L., Dattagupta, S., Schaperdoth, I., Jones, D. S., Druschel, G. K., and Eastman, D. (2008). Niche differentiation among sulfur-oxidizing bacterial populations in cave waters. ISME J. 2, 590-601. doi: 10.1038/ismej.2008.25

Macalady, J. L., Schaperdoth, I., Fulton, J. M., Freeman, K. H., and Hanson, T. E. (2010). Microbial biogeochemistry of a meromictic blue hole. Geochim. Cosmochim. Acta 74:A651.

Manske, A. K., Glaeser, J., Kuypers, M. M., and Overmann, J. (2005). Physiology and phylogeny of green sulfur bacteria forming a monospecific phototrophic assemblage at a depth of 100 meters in the Black Sea. Appl. Environ. Microbiol. 71, 8049-8060. doi: 10.1128/AEM.71.12.8049-8060.2

Marschall, E., Jogler, M., Henssge, U., and Overmann, J. (2010). Large-scale distribution and activity patterns of an extremely low-light-adapted population of green sulfur bacteria in the Black Sea. Environ. Microbiol. 12, 1348-1362. doi: $10.1111 / j .1462-2920.2010 .02178 . x$

Moisan, T. A., and Mitchell, B. G. (2001). UV absorption by mycosporine-like amino acids in Phaeocystis antarctica Karsten induced by photosynthetically available radiation. Mar. Biol. 138, 217-227. doi: 10.1007/s002270000424

Montesinos, E., Guerrero, R., Abella, C., and Esteve, I. (1983). Ecology and physiology of the competition for light between Chlorobium limicola and Chlorobium phaeobacteroides in natural habitats. Appl. Environ. Microbiol. 46, 1007-1016.

Mori, Y., Kataoka, T., Okamura, T., and Kondo, R. (2013). Dominance of green sulfur bacteria in the chemocline of the meromictic Lake Suigetsu, Japan, as revealed by dissimilatory sulfite reductase gene analysis. Arch. Microbiol. 195, 303-312. doi: 10.1007/s00203-013-0879-5

Mylroie, J. E., Carew, J. L., and Moore, A. I. (1995). Blue holes: definition and genesis. Carb. Evap. 10, 225-233. doi: 10.1007/BF03175407

Nagata, T. (1986). Carbon and nitrogen content of natural planktonic bacteria. Appl. Environ. Microbiol. 52, 28-32.

Overmann, J., Beatty, J. T., Hall, K. J., Pfennig, N., and Northcote, T. G. (1991). Characterization of a dense, purple sulfur bacterial layer in a meromictic salt lake. Limnol. Oceanogr. 36, 846-859. doi: 10.4319/lo.1991.36.5.0846

Overmann, J., Cypionka, H., and Pfennig, N. (1992). An extremely low-lightadapted phototrophic sulfur bacterium from the Black Sea. Limnol. Oceanogr. 37, 150-155. doi: 10.4319/lo.1992.37.1.0150

Overmann, J., and Pfennig, N. (1989). Pelodictyon phaeoclathratiforme sp. nov., a new brown-colored member of the Chlorobiaceae forming net-like colonies. Arch. Microbiol. 152, 401-406. doi: 10.1007/BF00425181

Pfennig, N. (1975). The phototrophic bacteria and their role in the sulfur cycle. Plant Soil 43, 1-16. doi: 10.1007/BF01928472

Planavsky, N. J., McGoldrick, P., Scott, C. T., Li, C., Reinhard, C. T., Kelly, A. E., et al. (2011). Widespread iron-rich conditions in the mid-Proterozoic ocean. Nature 477, 448-451. doi: 10.1038/nature10327

Post, A., and Larkum, A. W. (1993). UV-absorbing pigments, photosynthesis and UV exposure in Antarctica: comparison of terrestrial and marine algae. Aquat. Bot. 45, 231-243. doi: 10.1016/0304-3770(93)90023-P

Røy, H., Weber, H. S., Tarpgaard, I. H., Ferdelman, T. G., and Jørgensen, B. B. (2014). Determination of dissimilatory sulfate reduction rates in marine sediment via radioactive 35 S tracer. Limnol. Oceanogr. Methods 12, 196-211. doi: 10.4319/lom.2014.12.196

Schloss, P. D., Westcott, S. L., Ryabin, T., Hall, J. R., Hartmann, M., Hollister, E. B., et al. (2009). Introducing mothur: open-source, platform-independent, community-supported software for describing and comparing microbial communities. Appl. Environ. Microbiol. 75, 7537-7541. doi: 10.1128/AEM. 01541-09

Schwabe, S., and Herbert, R. A. (2004). Black holes of the Bahamas: what they are and why they are black. Quat. Int. 121, 3-11. doi: 10.1016/j.quaint.2004.01.019 
Seymour, J. R., Humphreys, W. F., and Mitchell, J. G. (2007). Stratification of the microbial community inhabiting an anchialine sinkhole. Aquat. Microb. Ecol. 50, 11-24. doi: 10.3354/ame01153

Shinn, E. A., Smith, G. W., Prospero, J. M., Betzer, P., Hayes, M. L., Garrison, V., et al. (2000). African dust and the demise of Caribbean coral reefs. Geophys. Res. Lett. 27, 3029-3032. doi: 10.1029/2000GL011599

Sogandares, F. M., and Fry, E. S. (1997). Absorption spectrum (340-640 nm) of pure water. I. Photothermal measurements. Appl. Optics 36, 8699-8709. doi: 10.1364/AO.36.008699

Stamatakis, A., Hoover, P., and Rougemont, J. (2008). A rapid bootstrap algorithm for the RAxML web servers. Syst. Biol. 57, 758-771. doi: 10.1080/ 10635150802429642

Stomp, M., Huisman, J., Stal, L. J., and Matthijs, H. C. (2007). Colorful niches of phototrophic microorganisms shaped by vibrations of the water molecule. ISME J. 1, 271-282. doi: 10.1038/ismej.2007.59

Swart, P. K., Arienzo, M., Broad, K., Clement, A., and Kakuk, B. (2010). Blue Holes in Bahamas: repositories of climate, anthropogenic, and archaeological changes over the past 300000 years. J. Earth Sci. 21:265. doi: 10.1007/s12583-010-0231-9

Takaichi, S. (2000). Characterization of carotenes in a combination of a C18 HPLC column with isocratic elution and absorption spectra with a photodiode-array detector. Photosynth. Res. 65, 93-99. doi: 10.1023/A:1006445503030

Tang, K.-H., and Blankenship, R. E. (2010). Both forward and reverse TCA cycles operate in green sulfur bacteria. J. Biol. Chem. 285, 35848-35854. doi: 10.1074/ jbc.M110.157834

Thamdrup, B. O., Finster, K., Hansen, J. W., and Bak, F. (1993). Bacterial disproportionation of elemental sulfur coupled to chemical reduction of iron or manganese. Appl. Environ. Microbiol. 59, 101-108.

Thamdrup, B., Fossing, H., and Jørgensen, B. B. (1994). Manganese, iron and sulfur cycling in a coastal marine sediment, Aarhus Bay, Denmark. Geochim. Cosmochim. Acta 58, 5115-5129. doi: 10.1016/0016-7037(94)90298-4

Thode-Andersen, S., and Jørgensen, B. B. (1989). Sulfate reduction and the formation of 35S-labeled FeS, FeS2, and S0 in coastal marine sediments. Limnol. Oceanogr. 34, 793-806. doi: 10.4319/lo.1989.34.5.0793

Viollier, E., Inglett, P. W., Hunter, K., Roychoudhury, A. N., and van Cappellen, P. (2000). The ferrozine method revisited: $\mathrm{Fe}(\mathrm{II}) / \mathrm{Fe}(\mathrm{III})$ determination in natural waters. Appl. Geochem. 15, 785-790. doi: 10.1016/S0883-2927(99) 00097-9
Visscher, P. T., Prins, R. A., and van Gemerden, H. (1992). Rates of sulfate reduction and thiosulfate consumption in a marine microbial mat. FEMS Microbiol. Lett. 86, 283-293. doi: 10.1016/0378-1097(92)90792-M

Weber, M., Faerber, P., Meyer, V., Lott, C., Eickert, G., Fabricius, K. E., et al. (2007). In situ applications of a new diver-operated motorized microsensor profiler. Environ. Sci. Technol. 41, 6210-6215. doi: 10.1021/es070200b

Widdel, F., Schnell, S., Heising, S., Ehrenreich, A., Assmus, B., and Schink, B. (1993). Ferrous iron oxidation by anoxygenic phototrophic bacteria. Nature 362, 834-836. doi: 10.1038/362834a0

Wieland, A., Zopfi, J., Benthien, M., and Kühl, M. (2005). Biogeochemistry of an iron-rich hypersaline microbial mat (Camargue, France). Microb. Ecol. 49, 34-49. doi: 10.1007/s00248-003-2033-4

Wright, S. W. (1991). Improved HPLC method for the analysis of chlorophylls and carotenoids from marine phytoplankton. Mar. Ecol. Prog. Ser. 77, 183-196. doi: $10.3354 /$ meps077183

$\mathrm{Xu}$, J., and Gao, K. (2010). Use of UV-a energy for photosynthesis in the red macroalga Gracilaria lemaneiformis. Photochem. Photobiol. 86, 580-585. doi: 10.1111/j.1751-1097.2010.00709.x

Xue, L., Zhang, Y., Zhang, T., An, L., and Wang, X. (2005). Effects of enhanced ultraviolet-B radiation on algae and cyanobacteria. Crit. Rev. Microbiol. 31, 79-89. doi: 10.1080/10408410590921727

Zopfi, J., Ferdelman, T. G., and Fossing, H. (2004). Distribution and fate of sulfur intermediates-sulfite, tetrathionate, thiosulfate, and elemental sulfurin marine sediments. Geol. Soc. Am. 379, 97-116. doi: 10.1130/0-8137-237 9-5.97

Conflict of Interest Statement: The authors declare that the research was conducted in the absence of any commercial or financial relationships that could be construed as a potential conflict of interest.

Copyright (c) 2018 Haas, de Beer, Klatt, Fink, Rench, Hamilton, Meyer, Kakuk and Macalady. This is an open-access article distributed under the terms of the Creative Commons Attribution License (CC BY). The use, distribution or reproduction in other forums is permitted, provided the original author(s) and the copyright owner are credited and that the original publication in this journal is cited, in accordance with accepted academic practice. No use, distribution or reproduction is permitted which does not comply with these terms. 